\title{
Devrim Arabasından Türkiye’nin Otomobiline: Toplumsal zihniyetin dönüşümü
}

\section{From "Devrim Arabası" to "Türkiye'nin Otomobili": The transformation of social mentality}

Gönderim Tarihi / Received: 25.05 .2021

Salih ARSLAN ${ }^{1}$

Kabul Tarihi / Accepted: 07.12.2021

Doi: https://doi.org/10.31795/baunsobed.942702

ÖZ: Çalışmanın konusu; "Devrim Arabası" ve "Türkiye'nin Otomobili” projelerine toplumun bakışındaki benzerlik ve farklılıklardır. Çalışmanın sorusu; toplumun iki benzer projeye yaklaşımındaki farklılıklar toplumsal zihniyetteki dönüşüm ile mi ilgilidir? Çalışmanın amacı; toplumun iki projeye yaklaşımındaki farklılığı ortaya çıkarmak ve bu farklılıklar üzerinden toplumsal zihniyetteki dönüşümü açıklamaktır. Çalışmanın yöntemi; konuya ilişkin gazete haberlerinin içerik analizi ve söylem analizi ile çözümlenmesidir. Analiz materyali; projelerin kamuoyuna tanıtıldığı dönemde ulusal gazetelerde yer alan haberlerdir. Çalışmada ulaşılan temel bulgular; iki projeye toplumun yaklaşımı önem verme ve başarılacağına inanma konusunda benzer, ilgi gösterme ve destekleme konusunda farklıdır. Çalışmada ulaşılan ana sonuç; Türkiye'de toplumsal zihniyet projeyi sahiplenme ve destekleme konusunda dönüşmüştür.

Anahtar Kelimeler: Toplumsal zihniyetin dönüşümü, Yeni kurumsal kuram, Devrim Arabas1, Türkiye'nin Otomobili

ABSTRACT: The subject of the study; the similarities and differences in the society's perceptions on two projects: "Devrim Arabası" (the car of the revolution) and "Türkiye'nin Otomobili" (Turkey's auto). The question of the study; is the difference in the society's approach to two similar projects related to the transformation in the social mentality? Purpose of the study; to reveal the differences between the approaches to the two projects and to explain the transformation in social mentality through these differences in approaches. The method of the study; it is the analysis of newspaper news on the subject with content analysis and discourse analysis. Analysis material; these are the news that appeared in national newspapers at the time the projects were introduced to the public. Basic findings of the study; the society's approach to the two projects is similar in giving importance and believing that they will be achieved, and different in showing interest and support. The main result reached in the study; social mentality in Turkey has turned on project ownership and support.

Keywords: Social mentality transformation, New institutional theory, Devrim Arabası, Türkiye'nin Otomobili

\footnotetext{
${ }^{1}$ Dr. Öğr. Üyesi, Eskişehir Osmangazi Üniversitesi, İktisadi ve İdari Bilimler Fakültesi / Siyaset Bilimi ve Kamu Yönetimi / Yönetim Bilimleri, salih.arslan@ogu.edu.tr, https://orcid.org/0000-0002-0602-3890
} 


\section{EXTENDED ABSTRACT}

\section{Literature review}

In the study, the similarities and differences in society's perceptions of the "Devrim Arabas1" (the car of the revolution) and "Türkiye'nin Otomobili" (Turkey's auto) projects were examined. In the study, the phenomenological approach, new institutionalism theory and structuralism theories were used, which suggest that the actions of social actors are shaped by the social mentality or structure. Social mentality is considered as schematic structures that both direct social action and help to understand it, as in the definitions of "invisible logic of social functioning" or "coded scenario of social logic". These theories claim that there is a relationship between both social action and social mentality, and social mentality and language. While language plays a role in the formation and spread of social mentality, social mentality shapes the actions of social actors. Based on this theoretical background, Van Dijk's sociocognitive approach has been adopted, claiming that discourse will reflect the social mentality.

Cognitive and institutional dimensions are the two basic components of social mentality (Farberman, 1970). Phenomenological institutionalism accepts cognitive processes as the central reason in the formation of institutions (Meyer, 2017; Hirsch, 1997), and institutions as the central reason in the formation of the social field (Jepperson, 1991). In this approach, everyday knowledge is shared, taken for granted, internalized, objectified, externalized, and socialized into an institution through social interaction and language (Berger \& Luckman, 1967). For this reason, it is assumed that institutions have the characteristic of representing social order or social relationship (Jepperson, 1991). Social cognition or mental schema also occurs simultaneously as institutions are constructed as social realities (Weick, 1993) with interactional ritual chains between social actors (Collins, 1981; Di Maggio, 1997; Powell and Colyvas, 2008). Therefore, there is a strong relationship between institutions and social cognition, and one reflects the other (Jepperson, 1991). Van Dijk (1993) "social cognition", Di Maggio (1997) "social scheme", Sewell (1992) "scheme" gives the names. Cognition or schemas are actually embedded in the minds of individuals, but they are social as they are commonly assumed, assumed and shared by members of society (Van Dijk, 1993). In this study, the use of the concept of "social mentality" was preferred among these concepts used to describe the mental structure of society.

\section{Methodology}

The study aims to find the answers to the questions of whether there is a difference in the society's perceptions of "Devrim Arabası" and "Türkiye'nin Otomobili" projects and, if so, whether this difference is related to the social mentality. Study questions; Does the society's perceptions to "Devrim Arabası" and "Türkiye'nin Otomobili" projects differ? Is this difference in perceptions related to the transformation in social mentality? In the study, the news in national newspapers during the period when the "Devrim Arabası" ve "Türkiye'nin Otomobili" projects were introduced to the public were analyzed. In the analysis, quantitative and qualitative content analysis and Van Dijk's discourse analysis methods were used. In the content analysis, the categories of showing interest, finding important, believing in achievement and supporting were determined and coded. In the discourse analysis, the language used and the words selected, associations and perceptions to be created, stereotyping and traditional acceptances, experience and memory, and social context were examined in the news.

\section{Findings and discussion}

In the study, it was found that both projects were welcomed in the society, there was a positive perception in both periods of giving importance and believing that they would be successful, and that the social perception in terms of showing interest and support turned into a positive perception from a neutral point of perception. Showing interest increased from 16\% to 63\%, support increased from $7 \%$ to $43 \%$. The content of the news shows that both projects are generally welcomed in the society. When examined in terms of sub-categories, there is a positive perception in both periods about giving importance and believing that it will be successful. It is understood that social attitude has changed significantly in terms of showing interest and support. Showing interest increased from $16 \%$ to $63 \%$, support increased from $7 \%$ to $43 \%$. These findings show that the society cares about the Devrim Arabas1 project and believes that it will be successful, but it cannot grasp the positive effect of its interest and support, or it cannot find the self-confidence to dare. Developments in other fields such as education 
level, workforce qualifications, intellectual capital, financial capital, infrastructure opportunities, purchasing power, technological ability, business experience, international collaborations and partnerships, mass communication opportunities have significantly increased interest and support in Türkiye'nin Otomobili project effect can be found. However, there are strong causal relationships between progress in these areas and the change in social mentality. Since the change of other social factors is only possible with the transformation of the social mentality, it is necessary to consider the impact of concrete elements such as technological talent and business experience together with the transformation in social mentality.

\section{Results and recommendations}

In the study, it was revealed that the society reached a level of consciousness in terms of showing interest in very important projects, taking initiative, expressing their support clearly and believing that their support will affect the result. For this reason, the study suggests that the social mentality has evidently transformed in terms of understanding the possible consequences of important projects, establishing a relationship between the project's fate and its own role, demonstrating self-confidence to take initiative actively and clearly offering support. 


\section{Giriş}

Toplumların hayatlarında kritik bazı olaylar, genelde ön plandaki aktörler açısından incelenmekte, sonuçlar olağanüstü yetenekli kahramanlar veya beceriksiz çıkarcı aktörlerle ilişkilendirilerek toplumsal zihniyet gibi yapısal etkenler ya arka plana itilmekte ya da ihmal edilmektedir. Aktör merkezli realist bakış açısının bu okuma biçimi sosyal olayların bilişsel, kültürel ve tarihsel boyutlarının yeterince anlaşılabilmesini sınırlandırmaktadır. Sosyal konuların tüm boyutlarıyla ortaya konulabilmesi, aktör merkezli realist çalışmaların yanı sıra bilişsel ve kültürel perspektifli kurumsal araştırmaların da yapılabilmesine bağlıdır. Bu çalışmada Türkiye'nin sosyal, ekonomik ve politik tarihi açısından önemli iki proje olan "Devrim Arabası" ile "Türkiye'nin Otomobili" girişimleri toplumsal zihniyet temelinde incelenmektedir. Çalışmada toplumun bu iki projeye yönelik tutum ve yaklaşımları ile bu tutum ve yaklaşımların arka planındaki zihniyetin ortaya çıkarılması amaçlanmakta ve zihniyet değişimi sorgulanmaktadır. Toplumsal kesimlerin projelere yönelik tutum ve yaklaşımları ulusal gazetelerdeki ilgili haberler incelenerek ortaya çıkarılmakta, haberlerde kullanılan dil ve söylem çözümlenerek toplumsal zihniyete ulaşılmaya çalışılmaktadır. Bunun için Van Dijk'in $(1988 ; 2001 ; 2008 ; 2009 ; 2014)$ söylem, toplum ve sosyal biliş arasında ilişki kurduğu sosyo-bilişsel yaklaşımı takip edilmektedir. Van Dijk'e (2009: 81; 2014: 91) göre ortak bilişsel ya da zihinsel modellere sahip toplum kesimleri aynı olaylar karşısında çoğunlukla benzer tutumlar ve davranışlar sergilemektedir. Sosyal kesimleri temsil eden gazeteler topluluk üyeleri ile aynı bilişsel modellere sahip olmalarından dolayı haberlerinde bu tutum ve yaklaşımları yansıtmaktadır (Van Dijk, 1988: 108; 2001: 97; 2008: 58). Bu nedenle gazetelerin belirli konulardaki haberleri çözümlendiğinde temsil etiikleri sosyal kesimlerin zihniyet yapılarına ulaşılabilmekte ve toplumdaki farklı kesimleri temsil eden gazeteler bir arada analiz edildiğinde toplumsal zihniyet ortaya çıkarılabilmektedir.

Türkiye literatüründe ekonomi ve teknoloji temelli projeleri toplumsal zihniyet temelinde inceleyen bir çalışmaya ulaşılamamıştır. Toplumsal zihniyetin araştırıldığı bazı çalışmalar içinde Anık (2011) toplumsal zihniyet aracıllğıyla sağlanabilecek toplumsal aidiyet ve sosyal kontrolün terör suçlarının önlenmesindeki rolünü, Yiğit (2009) Kabadayı filmi üzerinden Anadolu potlaç kültürünün zihinsel arka planını, Kala (2019) bireysel zihin ve toplumsal zihniyet ilişkisinde dilin rolünü incelemektedir. Ancak bu çalışmalar içerikleri itibariyle ülkenin ekonomik ve teknolojik gelişimini önemli ölçüde etkileyecek projelerin toplumsal zihniyet boyutunun açıklanmasına doğrudan katkı sunmamaktadır. Türkiye'nin Otomobili ile ilgili herhangi bir çalı̧̧ma bulunamamış, Devrim Arabası ile ilgili sadece Şimşek (2017) ve Aşık'ın (2020) çalışmaları tespit edilmiştir. Şimşek (2017) ve Aşık'ın (2020) çalışmaları Devrim Arabası projesini dönemin belgeleri ışı̆̆ında inceleyen tarih perspektifli çalışmalardır ve genelde dönemin siyasileri, yazarları, meslek ve ticaret odaları, akademisyenleri ve projenin teknik yürütücüleri açısından olaya yaklaşmakta ancak toplumsal zihniyete dair bir çözümlemede bulunmamaktadır. $\mathrm{Bu}$ araştırma, Devrim Arabası ve Türkiye'nin Otomobili projelerini toplumsal zihniyet temelinde incelemesi, Türkiye'de toplumsal zihniyetin dönüşümünü benzer iki olay üzerinden açıklamayı hedeflemesi nedeniyle literatüre katkı sunacaktır.

Çalışmada önce toplumsal zihniyet kavramı, bazı sosyal teorilerin zihniyet ya da biliş kavramlarına yaklaşımları ve toplumsal zihniyetin dönüşümünü açıklama biçimleri üzerinden ele alınacak, sonra dil ve zihniyet arasındaki ilişki tartışılacaktır. Son kısımda ise Devrim Arabası ve Türkiye'nin Otomobili projeleri ile ilgili ulusal gazetelerde yer alan haberler içerik analizi ve Van Dijk'in söylem analizi yöntemleriyle çözümlenecek ve her iki projeye toplumun yaklaşımı zihniyet açısından karşılaştırılacaktır.

\section{Literatür taraması}

\section{Toplumsal zihniyet ve zihniyetin dönüşümü}

Sosyal aktörlerin davranışlarını yalnızca çıkar ve niyet temelinde açıklamaya çalışan yaklaşımlar yetersiz olarak değerlendirilmekte (Friedland ve Alford, 1991: 232; Tolbert ve Zucker, 1996: 176; Scott, 2008: 431), kurumsal ve bilişsel boyutu ihmal ettikleri gerekçesiyle eleştirilmektedir (Meyer, 2010: 2). Fenomenoloji, etnometodoloji, sembolik etkileşimcilik, çerçeveler analizi, bilişsel sosyoloji gibi yaklaşımlar sosyal davranışın oluşumunda zihinsel ve bilişsel faktörleri temel belirleyici olarak kabul etmektedir (Collins, 2015: 246). Bu yaklaşımların temel açıklama biçimlerini örgüt teorisi içine etkili bir şekilde taşıyan ve sosyal davranışları bilişsel süreçler üzerinden açıklamaya çalışan Yeni Kurumsal 
Kuram (YKK) olmuştur (Hirsch, 1997: 1714; Scott, 2008: 428). Özellikle Berger ve Luckman'ın bilgi sosyolojisi, Garfinkel'in etnometodoloji çalışmaları, Weick'in örgütlenmenin sosyal psikolojisine yönelik araştırmaları YKK'a fenomenolojik temel sağlamıştır (Holt ve Sandberg, 2013: 227-228). YKK'nın kurucu teorisyenlerinden Meyer (2017: 835) bilişsel süreçler temelli açılamaları fenomenolojik kurumsalcılık; norm, güç ve çıkar temelli açılamaları sosyal örgütsel kurumsalcılık olarak tanımlamaktadır. Bu çalışmada teorik perspektif olarak YKK'ın fenomenolojik yaklaşımı benimsenmektedir. Fenemenolojik yaklaşım sosyal aktörlerin toplumsallaşma süreçlerinde hayatın somut unsurlarını belirli bir biçimde kavrayarak yetiştiğini, bu kavrayış biçimlerini düşünmeden benimseyerek doğal saydığını, olay ve olgular karşısında benimsenmiş düşünce kalıplarıyla tutum ve davranış geliştirdiğini varsaymaktadır. $\mathrm{Bu}$ nedenle kalıpların ve benimsetilmiş düşüncelerin irdelenmesini ve sorgulanmasını, olay ve olguların öğretildiği ya da aktarıldığı biçimde değil de gerçekte nasıl göründüklerini ve olduklarını ortaya çıkarmayı amaçlayan bir bakış açısıdır. Olay ve olgulara bilinç temelinde yaklaşmakta ve göründüğü gibi olduğu kabullenilen dünya ile ilgili her türlü yargının askıya alınması ile bilincin ortaya çıkarılabileceğini öne sürmektedir (Woff, 2002: 498-503).

Bilişsel ve kurumsal boyutlar toplumsal zihniyetin en temel iki bileşenidir (Farberman, 1970: 3). Fenomenolojik kurumsalcılık, bilişsel süreçleri kurumların oluşumunda (Hirsch, 1997: 1717; Meyer, 2017: 835), kurumları da sosyal alanın oluşumunda merkezi neden olarak kabul etmektedir (Jepperson, 1991: 153). Bu yaklaşımda gündelik bilgi sosyal etkileşim ve dil aracılığıyla paylaşılmakta, kanıksanmakta, içselleşmekte, nesnelleşmekte, dişsallaşmakta ve toplumsallaşarak kurum haline gelmektedir (Berger ve Luckman, 1967: 34-35). Bu nedenle kurumların sosyal düzen ya da sosyal ilişkiyi temsil etme özelliğine sahip olduğu varsayılmaktadır (Jepperson, 1991: 145). Sosyal aktörler arasındaki etkileşimsel ritüel zincirleriyle (Collins, 1981: 985) sosyal gerçeklikler olarak (Weick, 1993: 640) kurumlar inşa edilirken eş zamanlı olarak toplumsal biliş ya da zihinsel şema da oluşmaktadır (Di Maggio, 1997: 273-274; Powell ve Colyvas, 2008: 285). Bundan dolayı kurumlar ile toplumsal biliş arasında güçlü bir ilişki söz konusudur ve biri diğerini yansıtmaktadır (Jepperson, 1991: 153). Farberman'ın (1970: 3) toplumsal zihniyet olarak isimlendirdiği bu olguya Van Dijk (1993: 258) "sosyal biliş", Di Maggio (1997: 273) "toplumsal şema”, Sewell (1992: 4) "şema” adını vermektedir. Biliş ya da şemalar aslında bireylerin zihinlerinde gömülüdür ancak toplum üyeleri tarafindan ortak şekilde farz edildiği, varsayıldığg ve paylaşıldığ 1 için sosyaldir (Van Dijk, 1993: 257). Bu çalışmada toplumun zihinsel yapısını nitelemek için kullanılan bu kavramlar arasından "toplumsal zihniyet" kavramının kullanımı tercih edilmiştir.

Soyut bir olgu olarak toplumsal zihniyet tutum, davranış ve tavırlarda somut bir biçimde gözlemlenebilmektedir (Yiğit, 2009: 2494). Bu nedenle toplumsal ilişki biçimlerinin hemen her türünün toplumsal zihniyetle bağlantısı olduğu söylenebilir (Anık, 2011, 107). Toplumsal zihniyet sosyal hayata içkindir ve toplumsal değişimlerin bir parçasıdır (Yiğit, 2009: 2494). Bireysel zihnin oluşumunu ve onun toplumsal zihniyetle bağını dil sağlamaktadır (Kala, 2019: 176). Kikkawa (2014: xi) metaforik bir tarzla toplumsal zihniyeti, sosyal sistemin nasıl çalıştığını kontrol eden yazılım olarak tanımlamaktadır. Ona göre toplumsal zihniyet kavramı toplumsal işleyişin görünür olmayan mantığını çözmede anahtar rol oynama potansiyeline sahiptir.

Kikkawa'nın (2014: xi) "toplumsal işleyişin görünür olmayan mantığı" olarak tanımladığı toplumsal zihniyeti, Goffman (1983: 2) "sosyal mantığın kodlanmış senaryosu”, Giddens' (1984: 2) "düşünce yapıları", Di Maggio (1997: 274) "kültürel formlar" olarak nitelemektedir. Toplumsal zihniyet yaşam pratiklerinde alışkanlıklar, rutinler, gelenekler, törenler ve ritüeller gibi somut kültürel formlara (Meyer, 2010: 4) dönüşerek sosyal aktörlerin kurulu sosyal yapının bilişsel örüntüleri içinde hareket etmelerine neden olmakta (Di Maggio, 1997: 281) tercih, davranış ve tutumlarının benzeşmesini sağlamaktadır. Böylelikle sosyal kesimler ya da toplumlar aynı olay veya gelişmelere benzer tavır, tutum ve yaklaşımlar ortaya koymaktadır. Bu durum sosyal davranışların bilinçsizliğini değil, kültürel form ya da kurumlarda gömülü içselleşmiş bir bilince ya da mantığa sahip olunduğunu göstermektedir (Barley ve Tolbert, 1997: 102). Giddens (1984: 4) bunu "pratik bilinç" olarak tanımlamakta ve bu tür bir bilincin günlük faaliyetlere gömülü halde sosyal hayatın rutini içinde varlığını devam ettirdiğini ifade etmektedir. 
Toplumsal unsurların dinamik özellikler taşıması ve süreç içerisinde aktörlerin eylem ve tercihlerinin farklılaşması, teorik yaklaşımların sosyal değişimleri dikkate almalarını zorunlu kılmaktadır (Cohen, 2013: 307-308; Elliott, 2017: 170-171). Sosyal yapıdaki değişimlerin açıklanmasında iki temel yaklaşım bulunmaktadır. Bu iki yaklaşım sosyolojide makro-mikro, eylem-yapı, birey-toplum dualismi olarak bilinen ikilik problemine dayanmaktadır (Layder, 2006: 2-5). Bu yaklaşımlardan ilki; toplumu kendini oluşturan unsurlardan bağımsız bir varlık olarak varsayan ve onun zaman içinde kendiliğinden dönüştüğünü öne süren yapısalcı teoridir. Yapısalcılık bireyleri sosyal, kültürel, politik ve tarihi bağlamı içinde ele almakta, bireylerin tercih ve kararlarını bu makro yapıların belirlediğini öne sürmektedir. $\mathrm{Bu}$ nedenle sosyal değişimde insan özneye özel bir rol vermekten kaçınmaktadır (Bottomore ve Nisbet, 2002: 592; Giddens, 2013: 220; Elliott, 2017: 95). İkincisi; toplumu onu oluşturan unsurların bir toplamı olarak kabul eden ve toplumdaki değişimin kaynağının unsurlardaki değişme olduğunu iddia eden mikro etkileşimci yaklaşımdır. Bu yaklaşım toplumsal değişimde insan özneyi merkeze almakta ve toplumsal yapının insan bilinci ve faillikle inşa edildiğini savunmaktadır (Layder, 2006: 70-73; Collins, 2015: 245).

$\mathrm{Bu}$ iki sosyoloji geleneğinden birinin toplumsal eylemin üretilme süreçlerini açıklamasına rağmen tarihsel kolektif koşulları gözardı ettiği, diğerinin ise toplumsal bütünlüğü ortaya koymasına rağmen toplumsal hayatın üretildiği kolektif pratikleri ihmal ettiği yönündeki eleştiriler sosyal değişimi açıklamada farklı teorilerin ortaya çıkmasına neden olmuştur (Cohen, 2013: 307). Bunlar arasında Giddens'ın (1984) "Yapılaşma Teorisi” ve Bourdieu'nun (2018) "Pratik Teorisi” öne çıkmaktadır. Bu teoriler gündelik yaşam rutinlerinin, alışkanlıkların ve becerilerin toplumsal örgütlenmeyi nasıl etkilediği ve toplumsal yapının oluşmasına nasıl katkı sundukları konusuna eğilmektedir (Layder, 2006: 194; Elliott, 2017: 170). Giddens (1984: 17) yapılaşma kavramının, sosyal ilişkilerin dönüşüm kurallarını da içerdiğini öne sürmektedir. Ona göre yapılaşma kavramının zaman ve mekândaki sosyal ilişkilerle ve sosyal ilişkilerin dönüşüm kuralları ile ilgili olmak üzere iki boyutu vardır. Sosyal pratikleri sergileyen bireylerin kendi aralarındaki etkileşimde sosyal sistemin yapısal özellikleri olan kurallar ve kaynaklar da yeniden üretilmektedir. Kurallar yapının tekrar hangi ilkeler çerçevesinde üretileceğini belirlerken kaynaklar yapının tekrar üretilme kapasitesini temsil etmektedir. Kurallar ve kaynakların üretimi, sosyal hayatın daimi özellikleri olarak tanımlanan yapının içinde sürekli olarak tekrarlanmaktadır (Giddens, 1984: 15-24). Bourdieu (2018: 158) pratik teorisinde deneyimlenmiş alışkanlıkların (habitus) toplumsal olarak yapılandırılmış bir çevrede ortaya çıktığını, bu alışkanlıkların kalıcı yatkınlıklar oluşturarak kurallara itaatin bir ürünü olmadan, sonuçları bilinçli olarak hedeflemeden ve bunlara ulaşmak için gerekli işlemlere hâkim olmadan toplumsal pratikleri ve düzeni ürettiğini öne sürmektedir. Ona göre alışkanlığın ürettiği pratikler bir proje ya da planın hedefleriyle belirlenmiş göründüklerinde bile son tahlilde ürünü oldukları sosyal yapıyı yeniden üretmeye olanak sağlayacak şekilde geçmiş koşullarla belirlenmektedir. Bu tür bir pratik o anki doğrudanlığg içinde değerlendirilen duruma oranla aralarında diyalektik bir ilişki olduğu için hem görece özerk hem de zorunludur (Bourdieu, 2018: 158-161).

Sosyal teorideki yapısalcı ve mikro etkileşimci bu iki temel yaklaşım kendini YKK içinde Meyer (1977) ve Zucker (1977) çizgisi olarak göstermektedir. Zucker (1977: 726-730) kurumların oluşumunda bilişsel ve etkileşimsel süreçlerin etkisi üzerine yoğunlaşılmasını önermektedir. Bu öneri etkileşimsel ritüel zincirleri (Collins, 1981: 998) ve etkileşim ritüelleri (Goffman, 1983: 13) gibi mikro etkileşimci, rutin (Giddens, 1984) ve alışkanlık (Bourdieu, 2018) gibi sosyal pratik temelli yaklaşımlara yakındır. Meyer (1977) çizgisi ise kurumların formel örgüt yapılarını ve faaliyetlerini nasıl etkilediği üzerinde durulmasını önermekte (Meyer ve Rowan, 1977: 341) ve makro yapıların rutinler, kurallar ve anlamlarla kendi kendilerini yeniden ürettiğini iddia etmektedir (Jepperson ve Meyer, 2011: 64). Bu çizgi aktörü arka plana atan ve yapıyı öne çıkaran yapısalcı yaklaşıma yakındır. YKK içinde oluşan bu iki ana çizgi, kuramın sosyolojik düşünce geleneğinden büyük oranda etkilendiğinin bir göstergesidir.

Sosyal değişimi açılamada aktör ve yapı kavramlarından birini temel alan ya da her ikisini uzlaştırmaya çalışan yaklaşımlara bazı sosyologlar eleştirel yaklaşmaktadır. Wiley (1988: 260) makro-mikro seviyelerin birbirine indirgenemeyeceğini, Coleman (1986: 1321) makro süreçlerin mikro olayları belirlediğini öne sürmenin metodolojik holizm, mikro süreçlerin makro olayları meydana getirdiğini öne sürmenin metodolojik bireyselcilik olduğunu iddia etmektedir. Powell ve Colyvas (2008: 278) ise 
değişimle mikro süreçlerin, durağanlıkla makro süreçlerin eşleştirilmesinin hatalı olduğunu, bazı durumlarda bireylerin sosyal düzenin korunmasında güçlü bir rol oynayabileceğini, küreselleşme gibi makro olayların ise yerel düzenleri değiştirebileceğini öne sürmektedir. Görüldüğü üzere sosyal değişimin nasıl gerçekleştiği konusunda araştırmacılar arasında bir uzlaşı ve ikna edici ortak bir anlayış bulunmamakta ve sosyal bilimler sosyal değişimi tatmin edici bir şekilde açıklama konusunda başarısız görünmektedir (Meyer, 2008: 804). Sosyal yapıların oluşumu ve değişimi hakkında farklı görüş ve tartışmalara rağmen toplumsal hayatta hızlı ve yaygın sosyal değişimlerin oldukça nadir görüldüğü (Meyer, 2010: 6) ve değişimlerin uzun bir süreçte yavaşça meydana geldiği görüşü üzerinde genel bir uzlaşı bulunmaktadır (Hirsch, 1997: 1715).

\section{Dil ve toplumsal zihniyet ilişkisi}

Biliş ya da bilişsel şemalar aslında bireylerin zihninde bulunan olgulardır. Ancak bireyler topluluk halinde yaşamanın gereği olarak birbirleriyle etkileşime girmekte ve zihinsel yapılarındaki biçimleri birbirleriyle paylaşmaktadır. Bu alışveriş zihinsel yapılarda benzeşmeyi sağlamakta ve ortak toplumsal bir zihniyetin oluşmasına neden olmaktadır. Farberman (1970: 8-12) toplumsal zihniyetin oluşumunda içsel ve dişsal faktörleri önceleyen teorilerin dışında Mead'in (2017) her ikisini birleştiren ya da her ikisinin arasında yer alan bir zihniyet teorisi geliştirdiğini belirtmektedir. Ona göre Mead, zihin ve benliğin ilişkisini ortaya çıkarmak için iletişimsel sosyal süreçlere eğilmekte ve toplumsal benliğin bireysel seçim özgürlüğü ile toplumsal düzen zorunluluğu arasında ortak bir zeminde nasıl ortaya çıktığını göstermeye çalışmaktadır. Mead'in (2017: 181) birey ve toplum arasındaki ilişkiyi açıklarken kullandığ1 "genelleştirilmiş öteki" kavramı, bireye benlik bütünlüğünü veren toplumsal grubu işaret etmektedir. Birey ortak toplumsal eylemlere yönelik "genelleştirilmiş ötekinin" tavırlarını benimsediği sürece tam bir benlik geliştirebilmektedir. Bu nedenle Mead'e (2017: 182) göre toplumsal sürecin bireylerin davranışlarını etkilemesi ve topluluğun da üyelerinin davranışları üzerinde kontrol sağlayabilmesi ancak genelleştirilmiş ötekiyle mümkündür. Çünkü bu sayede toplumsal süreç bireyin düşünüşüne belirleyici olarak etki etmektedir. Böylelikle Mead etkileşim halindeki unsurlar bütünü olarak bir toplumsal zihin modeli ortaya koymaktadır (Collins, 2015: 263). Bu modele göre zihin, toplumsal süreç bireylerin deneyimlerine bir bütün olarak sızdığı zaman ortaya çıkmaktadır. $\mathrm{Bu}$ gerçekleştiğinde birey bir öz bilinç ve zihin sahibi olmakta ve bu sürece kendisiyle birlikte katılan diğer bireylerle ilişkisinin farkına varmaktadır. Bu farkındalık bireyin davranışlarını düzenlemesine ve kendini toplumsal sürece uyarlamasına neden olmaktadır (Mead, 2017: 162).

Mead'in (2017: 90-112-161) toplumsal zihniyet modelinde dil toplumsal sürecin önemli bir parçasıdır. Dil aracılı̆̆ıyla birey başkalarını etkilediği gibi kendini de etkilemektedir. Bunun için gerekli olan şey kişinin söylediği şeyi en başta kendisinin anlamasıdır. Anlam üzerindeki kontrol zihni oluşturmakta ve anlamın kontrolü dil ile sağlanmaktadır. Bu nedenle zihnin toplumsal süreçte kurulan dilsel iletişim aracılığıyla oluştuğu söylenebilir. Dildeki sözcükler herkes karşısında aynı tutumu takınmayı gerektiren evrensellerdir. Eğer ortak zihinsel yapı olmazsa bu ortak tutum mümkün olamayacaktır (Collins, 2015: 263). Bu nedenle Mead'in modelinde "genelleştirilmiş ötekinin" varlığ toplumsal zihniyeti, ortak düşünceyi, benzer tavırları ve ortak söylem evrenini ortaya çıkarmaktadır (Mead, 2017: 182). Sosyal kesimlerin üyelerinin aynı olaylar karşısında ortak tavır göstermeleri veya benzer söylemler kullanmalarının temel nedeni buradan kaynaklanmaktadır.

Dil ve toplumsal yapı arasında güçlü bir ilişki olduğunu öne süren bir başka sosyoloji geleneği yapısalcı teoridir (Bottomore ve Nisbet, 2002: 558; Giddens, 2013: 220; Elliott, 2017: 97; Sarup, 2019: 22). Yapısalcılara göre birey ve toplum dilin içinde dil aracıllı̆ı̆yla yapılaştırılmaktadır. Bu nedenle tüm toplumsal yapı mevcut dilsel pratiklerde gömülüdür (Collins, 2015: 280; Elliott, 2017: 172) ve dildeki işaretlerin anlamı sosyal yapı tarafından bireylere yüklenmiştir (Elliott, 2017: 96). Dili meydana getiren ilişkiler zihnin temel özelliklerine göre kalıplaşacakları için dil zihinsel süreçlerin kontrolü altında şekillenmekte ve zihinsel bir gerçeklik olarak toplumsal zihniyet yapılarını temsil etmektedir (Giddens, 2013: 221).

Sosyal yapı ile iç içe olan ve kendine özgü yapısal özelikleri bulunan dil (Fairclough, 2003: 24; Ainsworth ve Hardy, 2004: 155) sosyal yapının anlaşılmasına önemli katkılar sunmaktadır (Fairclough, 2003: 2; Fairhurst ve Cooren, 2004: 132). Basit bir anlam taşıyıcısı olmayan dil (Alvesson ve Karreman, 
2000a: 138), öznel anlamları sosyal gerçekliğe dönüştüren ve bu anlamları sınıflandıran önemli bir işleve sahiptir (Heracleous, 2004: 178). Kelime ve kavramlarla zihinsel şemaları biçimlendirmekte (Deetz, 1996: 192), bu şemalar aracılığıyla sosyal kimliklerin, sosyal ilişkilerin, bilgi ve inanç sistemlerinin üretimine katkıda bulunmakta (Phillips ve Malhotra, 2008: 703-704; Fairclough, 2013: 92), toplumsal zihniyetin sosyal alanda kökleşmesini sağlamaktadır (Berger ve Luckman, 1967: 85). Öte yandan kalıplaşmış dilsel formlar (Van Dijk, 1993: 257) kullanıcısına dair ilgiler içermekte (Alvesson ve Karreman, 2000b: 1129) ve kullanıcısının sosyal düzene uyduğunu göstermektedir (Fairclough, 2013: 92). Kategorik anlamlar içeren ve aksi düșünülemezlik özelliğine sahip olan dilsel formlar üzerinde kullanıcılar nadiren düşünmekte ve değerlendirme yapmaktadır (Van Dijk, 1993: 258). Bu formlar çözümlendiğinde, kullanan aktörlerin niyet, biliş, değer ve duygu gibi içsel yönleri ile sosyal pratik, etkileşim ve ilişki gibi dışsal yönleri açığa çıkarılabilmektedir (Alvesson ve Karreman, 2000a: 137-138; Putnam ve Fairhurst, 2001: 78).

Bunun için incelenen metinlerde birbirinden kopuk gibi görünen ifadelerin nasıl birlik oluşturduklarını göstermek gerekmektedir. Dil daima mümkün ifadeler için bir sistem meydana getirir ve belirli kurallar sunar (Foucault, 2014: 40). Foucault'nun (2014) söylemin düzeni olarak nitelediği söylemsel oluşumların birlikteliği, öz olarak söylemlerin metin (belgeler) içerisindeki dağılımıdır. Eğer bir metinde söylemsel birlik varsa dağılım, söylemsel oluşumları mümkün kılan ve yöneten bir sistem dahilinde gerçekleşmiştir. Dilin bölgesi ve söylemin nesnesinin alanında özelleşmiş bir pratik olarak söylem, tanımlanmış bir form halindedir. Söylem stratejilerinin seçimi dünya görüşü ve çıkarlardan bağımsız ortaya çıkmaz ancak dilin ve söylem alanının olanakları tarafından belirlenir. Söylemin oluşum sistemi söyleme ait nesne, strateji, ifade ve kavramları söylemin içine yerleştiren kurallar bütünüdür. Söylem çözümlemesi yapılırken nesnelerin, ifadelerin, kavramların ve stratejilerin metin içindeki dağılımına, birliğine ve düzenine bakılır (Foucault, 2014: 90-95). Bu ise nesne, ifade, strateji ve kavramların metin içindeki tekrarlanma biçimi ve dağılım sistemleri ortaya çıkarılarak yapılır. Böylelikle bir söylemsel pratiğe içkin ve kendi özelliği içinde onu tanımlayan kurallar bütünü keşfedilmiş olur (Foucault, 2014: 52-62).

\section{Yöntem}

$\mathrm{Bu}$ araştırmada Devrim Arabası ve Türkiye'nin Otomobili ile ilgili ulusal gazetelerde yer alan haberler çözümlenerek toplumsal zihniyet açığa çıkarılmaya çalışılmışır. Gazeteler ideoloji, norm, değer ve dünya görüşü bakımından ortak zihinsel modellere sahip oldukları sosyal kesimlerin tavır ve görüşlerini benimsemekte ve haberlerine yansıtmaktadır (Van Dijk, 2001: 114; 2008: 112; 2009: 31). Çünkü haberler gibi kamusal söylemler bireysel düşüncenin ya da ifadenin ürünü değil ait olduğu sosyal grubun zihinsel modelinin bir neticesidir (Van Dijk, 1988: 110). Sosyal kesimlerin üyelerinin belirli bir konudaki uzlaşısı, beklentisi ve yaklaşım mantığı gazetenin o konu ile ilgili yaptığı haberi yönlendirmekte, haber metninin dilini ve söylem biçimini belirlemektedir (Maigret, 2014: 52-314). Van Dijk'in $(1988 ; 2001 ; 2008 ; 2009$; 2014) sosyo-bilişsel yaklaşımı söylem, toplum ve sosyal biliş arasındaki ilişkiye odaklanarak söylemi onu üreten sosyal toplulukların üyeleri tarafindan paylaşılan ortak sosyal bilişin ürünü olarak kabul etmektedir (Van Dijk, 2001: 113-115). Bu yaklaşıma göre söylem, sosyal ve özneler arası bir zihinsel modelin ürünü olarak (Van Dijk, 2008: 119; 2009: 6) ait oldukları grupların sosyal bilişlerindeki inanç, bilgi, tutum, norm, değer ve ideolojileri yansıtmakta ve o grupların zihinsel modellerini temsil etmektedir (Van Dijk, 2009: 31-32). Düşünce, tutum ve ideolojiler sosyal bilişin özel formları olmalarından dolayı (Van Dijk, 1988: 108) ulusal gazetelerin Devrim Arabası ve Türkiye'nin Otomobili ile ilgili haberlerindeki tutum ve düşünceler incelendiğinde toplumsal zihniyete dair bulgulara ulaşılabilir.

\section{Devrim Arabast ve Türkiye'nin Otomobili}

Türkiye'de yerli otomobil üretme fikrinin somut bir projeye dönüştüğü ilk girişim "Devrim Arabası”dır. Bu fikrin oluşması ve gelişmesinde Türkiye'nin ekonomik olarak kalkınma isteği ve sanayi ülkesi olma arzusu ile askeri ve sivil ihtiyaçlar etkili olmuştur. Ancak fikrin projeye dönüşmesinde devrin sanayicilerinin, akademisyenlerinin ve meslek odalarının katkısı olsa da devlet ve hükümet yetkililerinin, bilhassa dönemin devlet başkanının, istekli ve kararlı oluşu önemli rol oynamıştır (Şimşek, 2017: 51-52; Aşık, 2020: 35-36). Dönemin devlet başkanının "yerli otomobil" üretme düşüncesini kamuoyuyla paylaşmasının ardından 1961 yılının ocak ayında 9 İstanbul firması bir araya 
gelerek “Türkiye Makine Motorlu Vasıta ve Yardımcı Sanayi Birliği”ni kurmuştur. Bu birlik Türkiye'de yerli otomobil, kamyonet ve kamyon üretilmesi için hükümet yetkilileriyle çeşitli görüşmeler gerçekleştirmiş, kongre ve basın toplantıları düzenlemiştir (Aşık, 2020: 36-38). Konu çeşitli meslek odalarının, ticaret ve sanayi birliklerinin gündemine gelmiş ve çeşitli toplantılarda konuşulmaya başlanmıştır. Hükümet nezdinde ise ilk defa 04 Mart 1961 tarihli Bakanlar Kurulu'nda ele alınmıştır (Aş1k, 2020: 39-41). Kabine üyelerinin bir kısmı projeyi desteklerken bir kısmı olumsuz bir kısmı da tarafsız görüş bildirmiştir. Sonuç olarak Bakanlar Kurulu, Sanayi Bakanı'nın otomobil endüstrisinde gelişmiş olan Avrupa ülkelerini incelemesi ve detaylı bir rapor hazırlanması yönünde karar vermiştir (Aşık, 2020: 41-47).

Sanayi Bakanı'nın Avrupa ülkelerindeki inceleme gezisinin akabinde Bakanlar Kurulu 30 Mart 1961 tarihinde toplanmış ve söz konusu incelemelerin ışığında konuyu tekrar ele almıştır (Aşık, 2020: 48-50). 22 Nisan 1961 tarihinde Başbakanlık'tan Ulaştırma Bakanlığı'na, Türkiye'ye özgü bir otomobil numunesi (prototip) yapılması ve bu işle ilgili TCDD'nin görevlendirilmesi yönünde bir resmi yazı gönderilmiştir. Bu yazı "Devrim Arabası" projesinin resmiyet kazandığını gösteren bir belge niteliği taşımaktadır (Şimşek, 2017: 51-52; Aşık, 2020: 48-50). Hükümetin bu konudaki kararının ardından 1517 Mayıs 1961 tarihlerinde Makine Mühendisleri Odası tarafından 1.Otomobil Endüstrisi Kongresi düzenlenmiştir. Kongreye hükümet yetkilileri, meslek odası üyeleri, sanayiciler ve bilim insanları katılmış ve görüşlerini bildirmiştir. Özellikle dönemin devlet başkanı ve sanayi bakanının görüşleri olumlu ve projenin başarılacağ yönünde olmuştur. Diğer katılımcılar da olumlu ya da olumsuz yönde eleştiri ve görüşlerini iletmişlerdir. Kongrenin onur konuğu olan Devlet Başkanı Gürsel konuşmasında; Türkiye'de otomobil yapılacağına olan inancını açık bir şekilde vurgulamıştır (Şimşek, 2017: 53-54; Aşık, 2020: 49-57).

$\mathrm{Bu}$ kongrenin ardından "yerli otomobil" üretimi basının ilgi odağına oturmaya başlamış ve konu gazeteler tarafından manşetlere taşınmıştır (Aşık, 2020: 52). Hem kongre öncesi hem de sonrasında basının daha çok devlet başkanı ve hükümet yetkililerinin Türkiye'de otomobil yapılabilmesi konusundaki beyanlarına yer verdiği görülmektedir (Aşık, 2020: 52-58). Henüz bu konuda bir proje başlatıldığı ve resmi kurumların görevlendirildiği ile ilgili husus kamuoyuyla paylaşılmamıştır (Şimşek, 2017: 74). Projeyi basından ve kamuoyundan olabildiğince gizli tutmaya çalışan hükümet, projede görevlendirilen personelin 19 Haziran 1961 günü Eskişehir'deki TCDD’ye ait Cer Atölyesinde bulunmalarını istemiştir (Şimşek, 2017: 89; Aşık, 2020: 68). Görevlendirilen idari ve teknik ekip fiilen 2 Temmuz 1961 günü çalışmalara başlamıştır (Aşık, 2020: 75). İlk numunelerin (prototip) üretilip test sürüşlerinin başladığı Ekim ayına kadar proje basından gizli tutulduğu için gelişmeler gazetelere yansımamıştır. İlk Türk otomobili numunesinin Eskişehir'de üretildiği ve ilgililerin önünde başarıyla çalıştı̆̆ yönünde ilk haberler Ekim ayının başından itibaren basında yer bulmaya başlamıştır. Daha sonra 19 Ekim 1961 tarihinde Ulaştırma Bakanı tarafından basına bir açıklama yapılmış ve ilk Türk otomobilinin üretildiği, tecrübe sürüşlerinin başarıyla sonuçlandığı ve Devlet Başkanı'na 26 Ekim 1961 tarihinde törenle verileceği açıklaması yapılmıştır (Aşık, 2020: 88-91).

“Türkiye'nin Otomobili" girişiminin 20 Ocak 2011 tarihinde TÜSİAD toplantısında dönemin başbakanının "babayiğit" olarak tanımladığı iş adamlarını yerli otomobil üretme konusunda yaptığı çağrı ile başladığı söylenebilir. 2015 yılına gelindiğinde ise Sanayi ve Teknoloji Bakanlığı ile TÜBİTAK öncülügünde uluslararası düzeyde tanınmış bir yabancı markanın fikri mülkiyet haklarının satın alınması yöntemiyle, markaya ait bir model üzerinden geliştirilen prototipler basınla paylaşılmış fakat bu proje sonuçlandırılamamıştır. Kasım 2017 tarihinde ise dönemin cumhurbaşkanı öncülüğünde diğer iş dünyası örgütlerinin de katılımıyla Türkiye'nin Otomobili Ortak Girişim Grubu, kısa adıyla TOGG, kurulmuş ve kamuoyuna açıklanmıştır. Eylül 2019 tarihinde dönemin Sanayi ve Teknoloji bakanı Türkiye'nin Otomobili ile ilgili ilk somut görseli sosyal medya hesabından paylaşmış ve bu paylaşım ciddi bir yankı uyandırmıştır. Bundan sonraki süreçte girişim belirli aralıklarla hem sosyal medyada hem de yazılı ve görsel medyada ele alınmış ve tartışılmıştır. Resmi tanıtımın yapılacağı tarih olarak 27 Aralık 2019 günü ilan edilmiş, toplum ve medya bu tarihe odaklanmış ve tanıtımın ardından çeşitli sosyal kesimler ve medya tanıtılan otomobil, otomobili üretecek şirket ve nasıl bir süreç yaşanacağına dair detaylı değerlendirmeler ve görüşler öne sürmüşlerdir (Habertürk, 2020). 


\section{Analiz materyali}

"Devrim Arabası" girişimi basından ve kamuoyundan gizli yürütülmeye çalışıldığı için projeye ilişkin ilk haber 04 Ekim 1961 tarihinde yapılmıştır. Daha sonra resmi tanıtımın yapıldığı 29 Ekim 1961 tarihine kadar birkaç haber basında yer almıştır. Ancak 29 Ekim Cumhuriyet Bayramı törenlerinde projeye ait prototip arabaların devlet başkanı ve hükümet düzeyinde tanıtımıyla haber sayısında ciddi bir artış olmuştur. Gazetelerin konuya yüksek ilgisi 01 Kasım 1961 tarihine kadar sürmüştür. Bu tarihten itibaren ise konunun gazetelerin gündeminden düştügü ancak 30 Kasım 1961 tarihine kadar az sayıda da olsa haber yapıldığı görülmektedir (Aşık, 2020: 90-129). Araştırmada 04 Ekim 1961 - 30 Kasım 1961 tarihleri arasındaki bütün ulusal gazeteler taranmıştır. Bu dönemde çıkan Akşam, Hürriyet, Milliyet, Tercüman, Vatan, Yeni Sabah, Cumhuriyet, Havadis, Son Havadis, Ulus, Yeni İstanbul, Dünya, Öncü, Kudret ve Son Posta olmak üzere 15 gazetede toplam 43 habere ulaşılmıştır. Haber sayısının sınırlı olması nedeniyle bütün gazete haberleri analize dâhil edilmiştir.

“Türkiye'nin Otomobili” ile ilgili Ocak 2011 ile Aralık 2019 arasında basında çok sayıda haber yapılmıştır. Yeni bir gelişme yaşandıkça konu basının gündemine gelmiş ve farklı yönleriyle ele alınmıştır. Ancak Kasım 2017 tarihinde TOGG'un resmi olarak kurulması ve tanıtılması ile haber sayısında artış yaşanmıştır. Eylül 2019 tarihinde ilk somut görselin paylaşılması ile haber yoğunluğu gözle görülür bir şekilde artmıştır. Ancak bütün toplum kesimlerinin konuya ilişkin görüşlerini ve tavırlarını net bir şekilde ifade etmeye başlaması ve bunların gazetelere yansıması resmi tanıtımın yapıldığ 27 Aralık 2019 tarihten itibaren olmuştur. Toplumun projeye ilişkin düşüncelerini daha doğru şekilde yansıtacağı için tanıtımın yapıldığı 27 Aralık 2019 ile 31 Ocak 2020 tarihleri arasında gazetelerde yer alan haberler analize dahil edilmiştir.

Kamuya açık gazete haberlerinin analiz materyali olarak kullanılması nedeniyle bu araştırma için etik kurul izni gerekmemektedir.

Tablo 1: Türkiye'de basilı ve internet gazeteleri

\begin{tabular}{|c|c|c|c|c|c|c|c|c|c|}
\hline \multicolumn{5}{|c|}{ Speedmedya (27.12.2019-31.01.2020) } & \multicolumn{2}{|l|}{ Similarweb (01.08.2020) } & \multicolumn{3}{|c|}{ Alexa (2020) } \\
\hline No & Gazete & $\begin{array}{l}\text { Ort. } \\
\text { Tiraj } \\
\text { (bin) }\end{array}$ & $\begin{array}{l}\text { Medya } \\
\text { Grubu }\end{array}$ & No & $\begin{array}{l}\text { En çok ziyaret edilen } \\
\text { haber siteleri (Türkiye) }\end{array}$ & $\begin{array}{r}\text { Ülke } \\
\text { Sira }\end{array}$ & No & $\begin{array}{l}\text { En değerli haber } \\
\text { siteleri (Türkiye) }\end{array}$ & $\begin{array}{r}\text { Ülke } \\
\text { Sira }\end{array}$ \\
\hline 1 & Sabah & 244 & Turkuvaz & 1 & Hurriyet.com & 6 & 1 & Hurriyet.com & 2 \\
\hline 2 & Sözcü & 243 & Estetik Y. & 2 & Milliyet.com & 10 & 2 & Milliyet.com & 3 \\
\hline 3 & Hürriyet & 215 & Demirören & 3 & Sozcu.com & 11 & 3 & Sozcu.com & 4 \\
\hline 4 & Posta & 165 & Demirören & 4 & Sabah.com & 12 & 4 & Haberturk.com & 6 \\
\hline 5 & Milliyet & 125 & Demirören & 5 & Haberturk.com & 17 & 5 & Sabah.com & 8 \\
\hline 6 & Akşam & 110 & Türkmedya & 6 & Takvim.com & 20 & 6 & Cumhuriyet.com & 17 \\
\hline 7 & Türkiye & 110 & İhlas Med. & 7 & Cumhuriyet.com & 42 & 7 & Takvim.com & 20 \\
\hline 8 & Yeni Şafak & 102 & Albayrak & 8 & Yeniakit.com & 66 & 8 & Yenicaggazetesi & 23 \\
\hline 9 & Takvim & 98 & Turkuvaz & 9 & Yenicaggazetesi & 73 & 9 & Gazetevatan.com & 24 \\
\hline 10 & Güneş & 61 & Türkmedya & 10 & Gazetevatan.com & 90 & 10 & Yeniakit.com & 26 \\
\hline 11 & Korkusuz & 58 & Estetik Y. & 11 & Yenisafak.com & 99 & 11 & Yenisafak.com & 29 \\
\hline 12 & Yeni Akit & 56 & Akit medya & 12 & Posta.com & 116 & 12 & Posta.com & 32 \\
\hline 13 & Yeni Asır & 51 & Turkuvaz & 13 & Aksam.com & 130 & 13 & Aksam.com & 35 \\
\hline 14 & Karar & 34 & Karar Yay. & 14 & Yeniasir.com & 211 & 14 & Karar.com & 38 \\
\hline 15 & Star & 30 & Türkmedya & 15 & Star.com & 239 & 15 & Dunya.com & 39 \\
\hline 16 & Cumhuriyet & 28 & Cumhuriyet & 16 & Karar.com & 293 & 16 & Milligazete.com & 41 \\
\hline 17 & Aydınlık & 14 & Aydınlık & 17 & Dunya.com & 373 & 17 & Star.com & 46 \\
\hline
\end{tabular}

Kaynak: alexa.com, 2020; similarweb.com, 2020; app.speedmedya.com, 2020

Gazeteler seçilirken hem basılı olması hem de internet yayınının olması ilk temel kriter olarak belirlenmiş ve 27 Aralık 2019 ile 31 Ocak 2020 tarihleri arasında ortalama olarak en çok traja sahip gazeteler tespit edilmiştir (bkz. Tablo 1). İkinci temel kriter olarak aynı medya grubuna sahip gazetelerden sadece birisi ve en çok traja sahip olanlar seçilmiştir. Turkuvaz medya (Sabah, Takvim, Yeni Asır), Demirören medya (Hürriyet, Milliyet, Posta), Estetik medya (Sözcü, Korkusuz), Türk medya (Akşam, Güneş, Star), İhlas medya (Türkiye), Albayrak medya (Yeni Şafak), Akit medya (Yeni Akit), Karar medya (Karar), Cumhuriyet medya (Cumhuriyet) ve Aydınlık medya (Aydınlık) gazetelerini çıkarmaktadır. Her bir medya grubunu temsilen en çok traja sahip (bkz. Tablo 1) Sabah, 
Hürriyet, Sözcü, Akşam, Türkiye, Yeni Şafak, Yeni Akit, Karar, Cumhuriyet ve Aydınlık gazeteleri ilk 10 olarak belirlenmiştir. Daha sonra en çok ziyaret edilen (bkz. Tablo 1) ve en değerli (bkz. Tablo 1) haber siteleri listesi yapılmıştır. Liste yapılırken gazetelerin hem basılı hem de internet yayınlarının olması temel kriter olarak gözetilmiş̧ir. Ancak Habertürk.com haber sitesinin hem en çok ziyaret edilen ve hem de en değerli haber siteleri sıralamasında ilk 5'te olması, ilgili gazetenin basılı geçmişi olması, bir medya grubunu (Ciner) temsil etmesi ve internet gazeteciliğinde etkili olması gibi nedenlerle ilk temel kriterde bir istisna olarak listeye dahil edilmiştir. Milliyet gazetesi de aynı medya grubundan (Demirören) başka bir gazete (Hürriyet) seçilmiş olmasına rağmen bütün sıralamalarda ilk 5 içinde olması, köklü gazetecilik geleneğine sahip olması ve basın dünyasındaki etkinliği gibi nedenlerle ikinci temel kriterde bir istisna olarak listeye eklenmiştir. Türkiye ve Aydınlık gazeteleri basılı traj listesinde ilk 10 içerisinde olmalarına rağmen en çok ziyaret edilen ve en değerli listelerinde ilk 10'a girememeleri (bkz. Tablo 1) nedeniyle listeden çıkarılmıştır. Böylelikle liste Hürriyet, Sabah, Sözcü, Milliyet, Habertürk, Cumhuriyet, Akşam, Yeni Şafak, Karar ve Yeni Akit gazetelerinden oluşturulmuştur.

\section{Analiz yöntemi}

Gazete haberlerinin çözümlenmesinde içerik analizi ve söylem analizi kullanılmıştır. İçerik analizi yaygın kullanılan dil yaklaşımlarından biri olarak kabul edilmekte (Fairhurst ve Cooren, 2004: 132) nicel ve nitel olmak üzere ikiye ayrılmaktadır. Nicel içerik analizinde incelenen materyalin belirli motiflerinin ne sıklıkta olduğu çözümlemenin esasını oluşturmaktadır. Nitel içerik analizinde ise genel yaklaşım sayılaştırma eğilimine girmeden, kuramsal olarak ya da çözümlemenin akışı içerisinde belirlenmiş kategori sistemini kullanmaktır (Mayring, 2011: 116-122). Bu araştırmada her iki teknikten de yararlanılmıştır. Metinlerin çözümlenmesi aşamasında ortak anlam kategorileri belirlenmiş ve bu kategoriler "ilgi gösterme", "önemli görme", "başarılacağına inanma" ve "destekleme" şeklinde adlandırılmıştır. Bir haber metninde birden fazla kategori ile ilişkili ifade bulunduğunda her bir kategori için ayrı kodlama yapılmışıı. Bu kategorik şemalar aracılığıyla metinlerdeki kavram ve ifade biçimlerinin birbirlerine nasıl bağlandıkları, birleştikleri, mantıksal yapı oluşturdukları, semantik içerik kazandıkları, örgütlendikleri ve dağılım gösterdikleri ortaya konulmuştur (Foucault, 2014: 77). Söylem analizi olarak Van Dijk'in (1988) yaklaşımı tercih edilmiştir. Van Dijk'e (1988: 24) göre söylem analizi dilin kullanıldığı her türlü metin, mesaj, konuşma, diyalog gibi iletişim biçimlerine metodolojik bir yaklaşımı ifade etmektedir. Van Dijk'in (2001: 113-115) yaklaşımı, söylem ile onu üreten sosyal toplulukların bilişsel modelleri arasındaki ilişkiyi ortaya çıkarmaya odaklanır. Bu yöntem aracılığıyla haber metinlerindeki söylem ile toplumsal zihniyet şemaları arasındaki ilişki gösterilmiştir.

\section{Bulgular ve tartışma}

\section{Devrim Arabasına ilişkin bulgular}

Devrim Arabası'na ilişkin haberler Tablo 2'de görüldüğ ü üzere olumlu \%48, olumsuz \%6 ve nötr \%46 şeklindedir. Haberlerin daha çok olumlu ve nötr yönde olduğu, olumsuz yönde haber sayısının düşük olduğu görülmektedir. Kategoriler açısından değerlendirildiğinde; "ilgi gösterme" kategorisinde \%16 olumlu ve $\% 84$ nötrdür. Önem verme" kategorisinde $\% 93$ olumlu, $\% 5$ olumsuz ve $\% 2$ nötrdür. "Başarılacağına inanma" kategorisinde \%74 olumlu, \%19 olumsuz, \%7 nötrdür. "Destek verme" kategorisinde $\% 7$ olumlu, $\% 3$ olumsuz ve $\% 90$ nötrdür.

Tablo 2'de görüldüğü üzere olumlu yönde haber "önem verme" (\%93) ve "başarılacağına inanma" (\%74) kategorilerinde öne çıkmaktadır. Nötr yönde haber "ilgi gösterme" (\%84) ve "destek verme" (\%90) kategorilerinde öne çıkmaktadır. Olumsuz yönde haber ise herhangi bir kategoride öne çıkmamaktadır. Bu bulgular projeye önem verildiğini ve başarılacağına inanıldığını ancak ilgi ve desteğin oldukça az olduğunu göstermektedir. 
Tablo 2: Dönemin gazetelerinde Devrim Arabas1

\begin{tabular}{|c|c|c|c|c|c|c|c|c|}
\hline $\begin{array}{l}\text { Dev } \\
\text { No }\end{array}$ & $\begin{array}{l}\text { im Arabas1 Haberleri } \\
\text { Gazete }\end{array}$ & Haber Sayıs1 & \multicolumn{2}{|c|}{$\begin{array}{l}\text { Gazetelerin İçerik Analizi } \\
\text { İceriğin Yönü }\end{array}$} & $\begin{array}{l}\text { Kategoriler } \\
\text { İlgi }\end{array}$ & \multirow{2}{*}{ Önem } & \multirow{2}{*}{$\frac{\text { Başarı }}{2}$} & \multirow{2}{*}{$\begin{array}{l}\text { Destek } \\
0\end{array}$} \\
\hline \multirow{4}{*}{1} & \multirow{4}{*}{ HÜRRİYET } & \multirow{4}{*}{4} & Olumlu & $8 / \% 50$ & 2 & & & \\
\hline & & & Olumsuz & $2 / \% 13$ & 0 & 0 & 2 & 0 \\
\hline & & & Nötr & $6 / \% 37$ & 2 & 0 & 0 & 4 \\
\hline & & & Toplam & $16 / \% 100$ & 4 & 4 & 4 & 4 \\
\hline \multirow{4}{*}{2} & \multirow{4}{*}{ VATAN } & & Olumlu & $8 / \% 50$ & 0 & 4 & 4 & 0 \\
\hline & & & Olumsuz & 0 & 0 & 0 & 0 & 0 \\
\hline & & 4 & Nötr & $8 / \% 50$ & 4 & 0 & 0 & 4 \\
\hline & & & Toplam & $16 / \% 100$ & 4 & 4 & 4 & 4 \\
\hline & & & Olumlu & $13 / \% 54$ & 1 & 6 & 5 & 1 \\
\hline & & & Olumsuz & 0 & 0 & 0 & 0 & 0 \\
\hline 3 & MILLIYET & 6 & Nötr & $11 / \% 46$ & 5 & 0 & 1 & 5 \\
\hline & & & Toplam & $24 / \% 100$ & 6 & 6 & 6 & 6 \\
\hline & & & Olumlu & $4 / \% 50$ & 0 & 2 & 2 & 0 \\
\hline & & & Olumsuz & 0 & 0 & 0 & 0 & 0 \\
\hline 4 & TERCUMAN & 2 & Nötr & $4 / \% 50$ & 2 & 0 & 0 & 2 \\
\hline & & & Toplam & 8 & 2 & 2 & 2 & 2 \\
\hline & & & Olumlu & $9 / \% 56$ & 1 & 4 & 4 & 0 \\
\hline & & 4 & Olumsuz & 0 & 0 & 0 & 0 & 0 \\
\hline 5 & AKŞAM & 4 & Nötr & $7 / \% 44$ & 3 & 0 & 0 & 4 \\
\hline & & & Toplam & $16 / \% 100$ & 4 & 4 & 4 & 4 \\
\hline & & & Olumlu & $6 / \% 75$ & 0 & 2 & 2 & 2 \\
\hline & & & Olumsuz & 0 & 0 & 0 & 0 & 0 \\
\hline 6 & YENI SABAH & 2 & Nötr & $2 / \% 25$ & 2 & 0 & 0 & 0 \\
\hline & & & Toplam & 8 & 2 & 2 & 2 & 2 \\
\hline & & & Olumlu & $7 / \% 35$ & 1 & 4 & 2 & 0 \\
\hline 7 & DÜNYA & 5 & Olumsuz & $4 / \% 20$ & 0 & 1 & 3 & 0 \\
\hline 1 & DUNYA & 5 & Nötr & $9 / \% 45$ & 4 & 0 & 0 & 5 \\
\hline & & & Toplam & 20 & 5 & 5 & 5 & 5 \\
\hline & & & Olumlu & $3 / \% 25$ & 0 & 2 & 1 & 0 \\
\hline 8 & & & Olumsuz & 0 & 0 & 0 & 0 & 0 \\
\hline 8 & ULUS & 3 & Nötr & $9 / \% 75$ & 3 & 1 & 2 & 3 \\
\hline & & & Toplam & 12 & 3 & 3 & 3 & 3 \\
\hline & & & Olumlu & $7 / \% 58$ & 1 & 3 & 3 & 0 \\
\hline & & & Olumsuz & 0 & 0 & 0 & 0 & 0 \\
\hline 9 & CUMHURIYET & 3 & Nötr & $5 / \% 42$ & 2 & 0 & 0 & 3 \\
\hline & & & Toplam & 12 & 3 & 3 & 3 & 3 \\
\hline & & & Olumlu & $5 / \% 42$ & 0 & 3 & 2 & 0 \\
\hline & & & Olumsuz & $1 / \% 8$ & 0 & 0 & 1 & 0 \\
\hline 10 & $\mathrm{ONCO}$ & 3 & Nötr & $6 / \% 50$ & 3 & 0 & 0 & 3 \\
\hline & & & Toplam & 12 & 3 & 3 & 3 & 3 \\
\hline & & & Olumlu & $4 / \% 50$ & 0 & 2 & 2 & 0 \\
\hline & & & Olumsuz & 0 & 0 & 0 & 0 & 0 \\
\hline 11 & KUDRET & 2 & Nötr & $4 / \% 50$ & 2 & 0 & 0 & 2 \\
\hline & & & Toplam & 8 & 2 & 2 & 2 & 2 \\
\hline & & & Olumlu & $2 / \% 25$ & 0 & 1 & 1 & 0 \\
\hline & & & Olumsuz & $3 / \% 38$ & 0 & 1 & 1 & 1 \\
\hline 12 & YENIISTANBUL & 2 & Nötr & $3 / \% 37$ & 2 & 0 & 0 & 1 \\
\hline & & & Toplam & 8 & 2 & 2 & 2 & 2 \\
\hline & & & Olumlu & $2 / \% 50$ & 0 & 1 & 1 & 0 \\
\hline & & & Olumsuz & 0 & 0 & 0 & 0 & 0 \\
\hline 13 & HAVADIS & 1 & Nötr & $2 / \% 50$ & 1 & 0 & 0 & 1 \\
\hline & & & Toplam & $4 / \% 100$ & 1 & 1 & 1 & 1 \\
\hline & & & Olumlu & $2 / \% 50$ & 1 & 1 & 0 & 0 \\
\hline 14 & SONHAVADIS & 1 & Olumsuz & $1 / \% 25$ & 0 & 0 & 1 & 0 \\
\hline 14 & SON HAVADIS & 1 & Nötr & $1 / \% 25$ & 0 & 0 & 0 & 1 \\
\hline & & & Toplam & $4 / \% 100$ & 1 & 1 & 1 & 1 \\
\hline & & & Olumlu & $2 / \% 50$ & 0 & 1 & 1 & 0 \\
\hline & & & Olumsuz & 0 & 0 & 0 & 0 & 0 \\
\hline 15 & SON POSTA & 1 & Nötr & $2 / \% 50$ & 1 & 0 & 0 & 1 \\
\hline & & & Toplam & $4 / \% 100$ & 1 & 1 & 1 & 1 \\
\hline & & & OLUMLU & $82 / \% 48$ & $7 / \% 16$ & $40 / \% 93$ & $32 / \% 74$ & $3 / \% 7$ \\
\hline & TOPI $\triangle \mathrm{M}$ & 43 & OLUMSUZ & $11 / \% 6$ & 0 & $21 \% 5$ & $8 / \% 19$ & $1 \% 3$ \\
\hline & IUPLAM & 43 & NÖTR & $79 / \% 46$ & $36 / \% 84$ & $1 / \% 2$ & $3 / \% 7$ & $39 / \% 90$ \\
\hline & & & TOPLAM & $172 / \% 100$ & $43 / \% 100$ & $43 / \% 100$ & $43 / \% 100$ & $43 / \% 100$ \\
\hline
\end{tabular}


Tablo 3: Devrim Arabasına ilişkin örnek ifadeler

\begin{tabular}{|c|c|c|}
\hline & Gazete/Tarih & Örnek İfade \\
\hline \multicolumn{3}{|l|}{ ÍlLGÍ } \\
\hline \multirow{3}{*}{ Olumlu } & $\begin{array}{l}\text { Hürriyet / } \\
30.10 .1961\end{array}$ & ...büyük bir kalabalık iki otomobilin etrafinda toplanmış merakla seyrediyor. \\
\hline & $\begin{array}{l}\text { Milliyet / } \\
30.10 .1961\end{array}$ & $\begin{array}{l}\text { Türk yapısı iki arabanın arkasında...üçüncü arabanın motoru da otomobillerle birlikte halka } \\
\text { teşhir edilmiştir. }\end{array}$ \\
\hline & $\begin{array}{l}\text { Cumhuriyet / } \\
30.10 .1961\end{array}$ & $\begin{array}{l}\text { Başkan Gürsel'in sarı otomobille Anıt-Kabire gelişi orada toplanmış bulunan halk tarafindan } \\
\text { coşkun şekilde alkışlanmıştır. }\end{array}$ \\
\hline Olumsuz & - & ( \\
\hline \multicolumn{3}{|l|}{ ÖNEM } \\
\hline \multirow{3}{*}{ Olumlu } & $\begin{array}{l}\text { Milliyet / } \\
30.10 .1961\end{array}$ & $\begin{array}{l}\text { Türk mühendis ve işçileri, geceli gündüzlü bir çalışma sonunda 'Türkiye'de otomobil } \\
\text { yapılamaz' iddiasını çürütmüşlerdir. }\end{array}$ \\
\hline & $\begin{array}{l}\text { Tercüman / } \\
30.10 .1961\end{array}$ & $\begin{array}{l}\text { Bu yapilan otomobil sanayii tarihimizde yeni bir hamle olarak kaydedilecektir. Fakat bir iki } \\
\text { otomobil bir şey ifade etmez, seri imalata gitmek lazım. }\end{array}$ \\
\hline & $\begin{array}{l}\text { Dünya / } \\
30.10 .1961\end{array}$ & $\begin{array}{l}\text { Türk sanayii çalışmalarında bir dönüm noktasıdır. Türk sanayii tarihini bunu mutlaka } \\
\text { yazacaktır. Yapamaz, yapılamaz diyenlere karşı mutlak bir muvaffakiyettir. Bir büyük emek } \\
\text { mahsulüdür. }\end{array}$ \\
\hline \multirow{3}{*}{ Olumsuz } & $\begin{array}{l}\text { Yeni İstanbul } \\
/ \\
01.11 .1961\end{array}$ & $\begin{array}{l}\text { Memleketimizde halli icap eden o derece önemli ekonomik meseleler mevcuttur ki, bir tek } \\
\text { Türk işçisinin dahi vaktini bu lüks otomobil için heba etmesi büyük bir milli kayıptır. }\end{array}$ \\
\hline & & $\begin{array}{l}\text { Eğer motorlu vasıtalar yapacaksak buna "müstehlik" olan binek otomobilinden mi, yoksa } \\
\text { istihsal yardımcısı olan traktör ve kamyondan mı başlayalım? }\end{array}$ \\
\hline & 61 & $\begin{array}{l}\text { Doğrusu ya, buna biz de cevap verebiliriz ve 'İmkânı varsa elbette kamyondan ve traktörden } \\
\text { deriz. }\end{array}$ \\
\hline \multicolumn{3}{|l|}{ BAŞARI } \\
\hline \multirow{3}{*}{ Olumlu } & $\begin{array}{l}\text { Hürriyet / } \\
30.10 .1961\end{array}$ & $\begin{array}{l}\text {..ilk otomobillerimizin de elbette birçok kusurları olacak ama zamanla mükemmelliğe } \\
\text { yaklaşılacaktır. Bugün bu otomobilleri beğenmeyenler, yarın beğenecekleri Türk yapıs1 } \\
\text { otomobile kavuşacaklardır. }\end{array}$ \\
\hline & $\begin{array}{l}\text { Vatan / } \\
30.10 .1961\end{array}$ & $\begin{array}{l}\text { Bir aşağılık duygusu ile bizde otomobil yapılamaz diyenler utansınlar. Hayır, işte bizde de } \\
\text { otomobil yapılabiliyor. }\end{array}$ \\
\hline & $\begin{array}{l}\text { Milliyet / } \\
30.10 .1961\end{array}$ & $\begin{array}{l}\text {...Devrim' adını taşıyan ilk Türk otomobilini } 120 \text { günde hizmete sokmuşlardır. Yüzde yüz } \\
\text { Türk işçiliği ve yüzde seksenden fazla Türk malı malzeme ile meydana gelen 'Devrim' hiçbir } \\
\text { yabancı otomobile benzememektedir. }\end{array}$ \\
\hline \multirow{6}{*}{ Olumsuz } & $\begin{array}{l}\text { Dünya / } \\
30.10 .1961\end{array}$ & $\begin{array}{l}\text { Benzin Bitiyor: Avrupa kafası ile otomobil yaptık. Ama Şark kafası ile benzin koyduk ve } \\
\text { burada kaldık. }\end{array}$ \\
\hline & Yeni İstanbul & $\begin{array}{l}\text { Devrim otomobilinin } \% 80 \text { yerli Türk malzemesi ile yapıldığına inanmak memleketimiz } \\
\text { muvacenehesinde çok güçtür. Motoru Türkiye'de nasıl yapılır? Kapısının tokmağını ve kilidini }\end{array}$ \\
\hline & 01.11 .1961 & yaptığımız bile şüphelidir. \\
\hline & Dünya / & Her motor parçasının tek tek taklidini dökerek bir otomobil yapmışı. Neden yapamazmışız? \\
\hline & 03.11 .1961 & Bu usul ile daha ince, daha dolambaçlı makinelerle de yapabiliriz. \\
\hline & $\begin{array}{l}\text { Son Havadis } \\
\text { / } \\
30.10 .1961\end{array}$ & $\begin{array}{l}\text {...50 metre ayrılmadan arabanın benzini bitmiş ve Gürsel gülerek otomobilden inmiştir. } \\
\text { Etrafındakilerin suçlu nazarlarını yakalayan Cumhurbaşkanı şunları... }\end{array}$ \\
\hline \multicolumn{3}{|l|}{ DESTEK } \\
\hline \multirow[b]{2}{*}{ Olumlu } & $\begin{array}{l}\text { Yeni Sabah / } \\
30.10 .1961\end{array}$ & irli bir tacir ilk arabayı 500 bin verip almak istiyor. \\
\hline & $\begin{array}{l}\text { Yeni Sabah / } \\
31.10 .1961 \\
\text { Milliyet / } \\
30.10 .1961\end{array}$ & $\begin{array}{l}\text {..99 firma oto sanayi için birleşmeye hazırdır. İleriki iltihaklarla bu rakamın } 36 \text { 'ya } \\
\text { yükseleceğini tahmin ediyorum. } \\
\text {..̇̇zmirli bir vatandaşın Türk otomobilini satın almak için müracaat ettiğini ve } 500 \text { bin lira } \\
\text { vermeyi kabul ettiğini söylemiştir. }\end{array}$ \\
\hline Olumsuz & $\begin{array}{l}\text { Yeni İstanbul } \\
\text { / } \\
01.11 .1961\end{array}$ & $\begin{array}{l}\text {...Türkiye'de otomobil imalatı ile uğraşmak bir israf ve lükstür...milyona yaklaşan maliyeti ile } \\
\text { ülke kaynakları boş yere harcanmaktadır. }\end{array}$ \\
\hline
\end{tabular}

Tablo 3'te görüldüğü üzere; "İlk Türk otomobili için 900 bin lira harcandl” (Hürriyet / 01.11.1961), "DEVRIM'in maliyeti" (Vatan / 01.11.1961) gibi maliyeti öne çıkaran haberler olumsuz bakış açısını yansitmaktadır. "C.Gürsel'in bindiği yerli otomobilin benzini bitti”" (Son Havadis / 30.10.1961), "Avrupa kafası ile otomobil yaptık. Ama Şark kafası ile benzin koyduk ve burada kaldık" (Dünya / 30.10.1961) gibi benzinin bitmesi hadisesini öne çıkaran haberler olumsuz yaklaşımın diğer örnekleridir. "bir tek Türk işçisinin dahi vaktini bu lüks otomobil için heba etmesi büyük bir milli kayıptır" (Yeni İstanbul / 01.11.1961), "her motor parçasının tek tek taklidini dökerek bir otomobil yapmışız” (Dünya / 03.10.1961) şeklindeki ifadeler doğrudan projenin başarılamayacağını ve bunun 
için harcanan paranın israf olduğunu vurgulamaları nedeniyle olumsuz yaklaşımın diğer örnekleri olarak sunulabilir.

"Türk mühendis ve işçileri, 'Türkiye'de otomobil yapılamaz' iddiasını çürütmüşlerdir" (Milliyet I 30.10.1961), "Bu yapllan otomobil sanayii tarihimizde yeni bir hamle olarak kaydedilecektir" (Tercüman / 30.10.1961), "Türk sanayii çalışmalarında bir dönüm noktasıdır. Türk sanayii tarihi bunu mutlaka yazacaktır" (Dünya / 30.10.1961) gibi ifadeler projenin önemine dair olumlu bir bakış açısını yansıtmaktadır. Ayrıca "Türk tipi otomobil imal edilecek" (Akşam / 31.10.1961), "İlk Türk otomobili DEVRIM" (Vatan / 31.10.1961), "Illk Türk otomobili" (Ulus / 30.10.1961), "Türk yapısı ilk otomobil" (Tercüman /30.10.1961) gibi "yerli ve milli" vurgusu yine projenin önemini işaret eden ifadeler olarak gösterilebilir.

“Türkiye'de otomobil yapılamaz iddiası Devrim'le çürütüldü” (Milliyet / 30.10.1961), "ilk otomobillerimizin de elbette birçok kusurları olacak ama zamanla mükemmelliğe yaklaşılacaktır" (Hürriyet / 30.10.1961), "bir aşağıllı duygusu ile bizde otomobil yapılamaz diyenler utansınlar. Hayır, işte bizde de otomobil yapılabiliyor" (Vatan / 30.10.1961) gibi ifadeler projenin başarıya ulaşacağına olan inanc1 yansitmaktadır.

"9 firma oto sanayi için birleşmeye hazırdır. Illeriki iltihaklarla bu rakamın 36'ya yükseleceğini" (Yeni Sabah / 31.10.1961), "İzmirli bir vatandaşın Türk otomobilini satın almak için müracaat ettiğini ve 500 bin lira vermeyi kabul ettiğini" (Milliyet / 30.10.1961) ifadeleri projenin farklı toplum kesimleri tarafından desteklendiğini göstermektedir.

Van Dijk (1988: 107) sosyal biliş temelli söylem çözümlemesinde, haberlerin kullanılan dil ve seçilen kelimeler, yapılan çağrışımlar ve oluşturulmak istenen algı, steriotipleştirme ve geleneksel kabuller, tecrübe ve hafiza ile sosyal bağlam bakımından incelenmesini önermektedir. "DEVRIM'in maliyeti" ve "lüks otomobil" gibi ifadelerle projenin çok pahalıya mal olacağına dair bir çağrışım yapılmakta ve toplumun ödediği vergilerin heba olacağ 1 yönünde bir algı oluşturulmaktadır. "her motor parçasının tek tek taklidini dökerek" ve "kapısının tokmağını ve kilidini yaptığımız bile şüphelidir" şeklindeki ifadeler ile aslında bunun bir Türk otomobili olmadığı, Illk Türk Otomobili şeklinde sunularak toplumun yanıltıldığı ve Türkiye'nin dünya standartlarında bir otomobil yapamayacağı kastedilmektedir. "Şark kafası ile benzin koyduk" ifadesinde bir steriotipleştirme sözkonusudur ve doğu olarak zihinlerde kategorize edilen büyük çerçevenin içine Türkiye mahkûm edilmektedir. Doğulu bir ülke olarak Türkiye batı zihninin ürünü olan otomobili çağdaş standartlarda üretemez kabulü ifadeye yön vermektedir. $\mathrm{Bu}$ tür söylemler mevcut durumu kabullenen, özgüveni düşük, büyük projeleri maceraperestlik olarak gören bir zihniyetin yansımasıdır. Bu zihniyet gelişmiş ve geri kalmış toplumlar arasında kolaylıkla kapatılamayacak "büyük boşluk" olduğu tezlerini peşinen kabullenmekte, bu açığ kapatma niyetiyle gerçekleştirilen bütün girişimleri küçümsemekte, büyük hedef ve projeleri hayalcilikle itham etmektedir. Bu yaklaşım kendisini "realist” olarak sunmakta, maliyet, israf, lüks ve emeğin hebası gibi ifadelerle tavırlarının mantıksal ve haklı gerekçelere dayandığı izlenimi oluşturmaya çalışmaktadır.

Haberlerde yer alan "Türkiye'de otomobil yapılamaz iddiasını çürütmüşlerdir", "Türk sanayii çalışmalarında bir dönüm noktasıdır", "Illk Türk otomobili" gibi ifadeler hem projenin önemini göstermekte hem de geleneksel ön yargıların aksine projenin başarılacağına olan inancı vurgulamaktadır. Bazı oto sanayi firmalarının birleşmesi ve birkaç vatandaşın Türk otomobili satın almak için müracaat etmesine yönelik ifadeler toplumsal desteğin var olduğuna işaret etmektedir. Ancak bu tür ifadelerin sayıca az olması ve vurgularındaki zayıflık bu desteğin güçlü olmadığını göstermektedir. "Illk Türk otomobili" şeklinde bir nitelemenin yapılması milli ve yerli olmayı çağrıştırırken, "Türk sanayinde bir dönüm noktasıdır" şeklindeki vurgu projenin kritik öneme sahip olduğu algısına yöneliktir. "otomobil yapılamaz iddiasını çürütmüşlerdir" şeklindeki ifadeler ile geleneksel ön kabullerin bu projeyle yıkıldığı ve artık bir hükmünün olmadığı ima edilmektedir. Bu tür söylemler geri kalmışlı̆̆ kabullenmeyen, öğrenilmiş çaresizliğe rıza göstermeyen, geleneksel alg1, tipleştirme ve yargılara itiraz eden, mevcut durumun büyük ve zor projelerin başarılmasıyla değişebileceğinin bilincinde olan bir toplumsal zihniyetin yansımalarıdır. Ancak "bir iki otomobil bir şey ifade etmez, seri imalata gitmek lazım", "ilk otomobillerimizin de elbette birçok kusurları olacak 
ama zamanla mükemmelliğe yaklaşılacaktır" şeklindeki ifadeler başarılmak istenilen hedefin zorluğunun, mevcut şart ve imkânların yeterince uygun olmadığının farkında olunduğunu göstermektedir. Projedeki zorluğun farkında olunması ve toplumsal özgüvenin yeterince yüksek olmaması çekingen ve temkinli bir dilin kullanılmasına neden olmaktadır. Bu temkinli dil projenin önemli görülmesi ve başarılacağına inanılmasına rağmen somut ilgi ve desteğin yeterince gösterilmemesini de kısmen izah etmektedir. Temkinli olma ve çekingenlik toplumsal özgüven ve öz yeterlilik algısının kırılganlığına işaret etmekle birlikte toplumsal desteğin katkılarını kavrama konusunda bilinçliliğgin oluşmadığını da göstermektedir.

\section{Türkiye'nin Otomobiline ilişkin bulgular}

Türkiye'nin Otomobili'ne ilişkin haberler Tablo 4'te görüldüğü üzere olumlu \%57, olumsuz \%1 ve nötr \%42 şeklindedir. Haberlerin daha çok olumlu ve nötr yönde olduğu, olumsuz yönde haber sayısının oldukça düşük olduğu görülmektedir. Kategoriler açısından değerlendirildiğinde; "ilgi gösterme" kategorisinde $\% 63$ olumlu ve $\% 37$ nötrdür. "Önem verme" kategorisinde $\% 60$ olumlu, $\% 2$ olumsuz ve $\% 38$ nötrdür. "Başarılacağına inanma" kategorisinde \%61 olumlu, \%2 olumsuz, \%37 nötrdür. "Destek verme" kategorisinde $\% 43$ olumlu, $\% 1$ olumsuz ve $\% 56$ nötrdür. Olumlu yönde haber "ilgi gösterme" (\%63), "önem verme" (\%60) ve "başarılacağına inanma" (\%61) kategorilerinde öne çıkmaktadır. Nötr yönde haber sadece "destek verme" (\%56) kategorisinde öne çıkmaktadır. Bu bulgular projeye ilgi gösterildiğini, önem verildiğini ve başarılacağına inanıldığını göstermektedir. Toplumun projeye desteği konusunda nötr bir dil öne çıksa da olumlu dil oranının \%43 ile yüksek olduğu görülmektedir.

“Türkiye'nin Otomobili" resmi tanıtımının ardından bağımsız bir araştırma firması Türkiye genelinde bir anket yapmıştır (Anadolu Ajansı, 2020). Anket sonuçlarına göre katılımcıların yüzde 95,4'ü bu araçları gördügünü ve Türkiye'nin Otomobili'nden haberdar olduklarını ifade etmiştir. Projeyi destekleme oranı yüzde 97,6 ve otomobilden satın almak isteyenlerin oranı \%89'dur. Tasarımların beğenilme oranı yüzde 98,4 ve Türkiye'nin Otomobili'nin bir dünya markası olabileceğine inanma oranı yüzde 90,3'tür. Anketin sonuçları rakamsal olarak yüksek olsa da çalışmanın sonuçlarını desteklemektedir. Türkiye'nin Otomobili ile ilgili olumsuz haber sayısı toplamda 7 ve oran olarak \%1, olumlu haber sayıs 389 ve oran olarak \%57'dir. Bu nedenle projenin toplumun farklı kesimlerince olumlu karşılandığı görülmektedir. Ancak özellikle iktidara yakın olan kesimlerde daha olumlu bir tavır belirgin iken muhalif kesimlerde nötr tavrın hakim olduğu söylenebilir.

Tablo 5'te görüldügü üzere Habertürk, Sözcü ve Cumhuriyet genelde nötr bir dil tercih etmişlerdir. Bu gazetelerin bazı eleştirilerde bulundukları ve olumsuz bazı noktalara vurgu yaptıkları görülmektedir. Ancak olumsuz bir tavır veya yaklaşım olarak kabul edilecek bir dil kullanmaktan kaçındıkları söylenebilir. Muhalif sağ liberal olarak nitelenebilecek Karar gazetesinin "Türkiye'nin otomobiline her kesimden destek geldi” (Karar / 29.12.2019) ifadesi bu tespiti desteklemektedir.

Haberlerde ilgi anlamında; "Türkiye'nin otomobili dünya gündeminin ilk sırasına çıktı" (Sabah / 27.12.2019), "Yerli otomobil tasartm ve özellikleri ile hayran bıraktı" (Hürriyet / 27.12.2019), "Türkiye'nin Otomobili toplumun her kesiminden beğeni topladl" (Milliyet / 28.12.2019), "Büyük beğeni topladı! Türkiye'nin Otomobili dünya gündemine damga vurdu” (Akşam / 28.12.2019) şeklindeki ifadeler toplumsal ilginin oldukça yüksek olduğunu göstermektedir. Önem anlamında; "Erdoğan'dan yerli otomobil mesajl: Geleceğin teknolojisi", (Hürriyet / 28.12.2019), "Yerli otomobil Türkiye'de voltaji yükseltecek" (Sabah / 04.01.2020), "İste Türkiye'nin otomobilinin tetikleyeceği sektörler" (Akşam / 31.12.2019), "Türkiye'nin Otomobili üretimi okullarda heyecan yarattı" (Milliyet / 08.01.2020) biçimindeki ifadeler toplumun girişimi oldukça önemli gördüğünü göstermektedir.

Başarı anlamında; "Ön alım talepleri başladı! Yerli otomobil tek elden" (Sabah / 02.01.2020), "Yerli otomobil burada üretilecek" (Hürriyet / 04.01.2020), "Yerli otomobil fiyatları belli oldu mu? Yerli otomobil sipariş talebi" (Milliyet / 02.01.2020), "Yerli otomobil için talep toplama başladı! İşte ön ödeme rakamı" (Akşam / 31.12.2019) şeklindeki ifadeler girişimin gerçekleştirileceğine ve başarıya ulaşacağına dair inancın tam ve kesin olduğunu göstermektedir. Destek anlamında; "YÖK, Türkiye'nin Otomobili"ne doktorall mühendis yetiştirecek" (Sabah / 07.01.2020), "Ankaralı otomobil ve şoför esnafindan Türkiye'nin Otomobili'ne destek" (Hürriyet / 29.12.2019), "Türkiye'nin Otomobili"ne 
Edirne'den de destek geldi" (Milliyet / 06.01.2020), "Yavaş ve İmamoğlu'ndan yerli otomobil paylaşımı" (Cumhuriyet / 27.12.2019) biçimindeki ifadeler toplumun farklı kesimlerinden girişime önemli ve ciddi bir destek verildiğini göstermektedir.

Tablo 4: Dönemin gazetelerinde Türkiye'nin Otomobili

\begin{tabular}{|c|c|c|c|c|c|c|c|c|}
\hline \multicolumn{3}{|c|}{ Türkiye'nin Otomobili Haberleri } & \multirow{2}{*}{\multicolumn{2}{|c|}{$\begin{array}{l}\text { Gazetelerin İçerik Analizi } \\
\text { İçeriğin Yönü }\end{array}$}} & \multirow{2}{*}{$\begin{array}{l}\text { Kategoriler } \\
\text { İlgi }\end{array}$} & \multirow{3}{*}{ Önem } & \multirow{3}{*}{$\begin{array}{l}\text { Başarı } \\
20\end{array}$} & \multirow{3}{*}{$\begin{array}{l}\text { Destek } \\
20\end{array}$} \\
\hline No & Gazete & Haber Sayıs1 & & & & & & \\
\hline \multirow{4}{*}{1} & \multirow{4}{*}{ HÜRRİYET } & \multirow{4}{*}{41} & Olumlu & $92 / \% 56$ & $27-3$ & & & \\
\hline & & & Olumsuz & 0 & 0 & 0 & 0 & 0 \\
\hline & & & Nötr & $72 / \% 44$ & 14 & 16 & 21 & 21 \\
\hline & & & Toplam & $164 / \% 100$ & 41 & 41 & 41 & 41 \\
\hline \multirow{4}{*}{2} & \multirow{4}{*}{ SABAH } & \multirow{4}{*}{25} & Olumlu & $51 / \% 51$ & 14 & 15 & 12 & 10 \\
\hline & & & Olumsuz & 0 & 0 & 0 & 0 & 0 \\
\hline & & & Nötr & $49 / \% 49$ & 11 & 10 & 13 & 15 \\
\hline & & & Toplam & $100 / \% 100$ & 25 & 25 & 25 & 25 \\
\hline \multirow{4}{*}{3} & \multirow{4}{*}{ MİLLIYET } & \multirow{4}{*}{22} & Olumlu & $64 / \% 73$ & 18 & 16 & 16 & 14 \\
\hline & & & Olumsuz & 0 & 0 & 0 & 0 & 0 \\
\hline & & & Nötr & $24 / \% 27$ & 4 & 6 & 6 & 8 \\
\hline & & & Toplam & $88 / \% 100$ & 22 & 22 & 22 & 22 \\
\hline \multirow{4}{*}{4} & \multirow{4}{*}{ HABERTÜRK } & \multirow{4}{*}{12} & Olumlu & $17 / \% 35$ & 6 & 4 & 6 & 1 \\
\hline & & & Olumsuz & $2 / \% 5$ & 0 & 1 & 1 & 0 \\
\hline & & & Nötr & $29 / \% 60$ & 6 & 7 & 5 & 11 \\
\hline & & & Toplam & $48 / \% 100$ & 12 & 12 & 12 & 12 \\
\hline \multirow{4}{*}{5} & \multirow{4}{*}{ AKŞAM } & \multirow{4}{*}{9} & Olumlu & $27 / \% 75$ & 8 & 7 & 6 & 6 \\
\hline & & & Olumsuz & 0 & 0 & 0 & 0 & 0 \\
\hline & & & Nötr & $9 / \% 25$ & 1 & 2 & 3 & 3 \\
\hline & & & Toplam & $36 / \% 100$ & 9 & 9 & 9 & 9 \\
\hline \multirow{4}{*}{6} & & & Olumlu & $10 / \% 28$ & 4 & 2 & 3 & 1 \\
\hline & sö7CÜ & & Olumsuz & 0 & 0 & 0 & 0 & 0 \\
\hline & SULCU & 9 & Nötr & $26 / \% 72$ & 5 & 7 & 6 & 8 \\
\hline & & & Toplam & $36 / \% 100$ & 9 & 9 & 9 & 9 \\
\hline & & & Olumlu & $7 / \% 25$ & 2 & 2 & 1 & 2 \\
\hline 7 & & & Olumsuz & $5 / \% 18$ & 0 & 2 & 2 & 1 \\
\hline 1 & СОVНUКТУЕ & I & Nötr & $16 / \% 57$ & 5 & 3 & 4 & 4 \\
\hline & & & Toplam & $28 / \% 100$ & 7 & 7 & 7 & 7 \\
\hline & & & Olumlu & $44 / \% 65$ & 11 & 11 & 16 & 6 \\
\hline 8 & & & Olumsuz & 0 & 0 & 0 & 0 & 0 \\
\hline$\gamma$ & YENI ŞAFAK & 17 & Nötr & $24 / \% 35$ & 6 & 6 & 1 & 11 \\
\hline & & & Toplam & $68 / \% 100$ & 17 & 17 & 17 & 17 \\
\hline & & & Olumlu & $44 / \% 73$ & 11 & 12 & 13 & 8 \\
\hline & & & Olumsuz & 0 & 0 & 0 & 0 & 0 \\
\hline 9 & YENI AKII & 15 & Nötr & $16 / \% 27$ & 4 & 3 & 2 & 7 \\
\hline & & & Toplam & $60 / \% 100$ & 15 & 15 & 15 & 15 \\
\hline & & & Olumlu & $33 / \% 59$ & 7 & 9 & 11 & 6 \\
\hline 10 & KARAR & 14 & Olumsuz & 0 & 0 & 0 & 0 & 0 \\
\hline 10 & 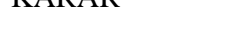 & 14 & Nötr & $23 / \% 41$ & 7 & 5 & 3 & 8 \\
\hline & & & Toplam & $56 / \% 100$ & 14 & 14 & 14 & 14 \\
\hline & & & OLUMLU & $389 / \% 57$ & $108 / \% 63$ & $103 / \% 60$ & $104 / \% 61$ & $74 / \% 43$ \\
\hline & TOPLAM & & OLUMSUZ & $7 / \% 1$ & 0 & $3 / \% 2$ & $3 / \% 2$ & $1 / \% 1$ \\
\hline & TUPLAIV & $1 / 1$ & NÖTR & $288 / \% 42$ & $63 / \% 37$ & $65 / \% 38$ & $64 / \% 37$ & $96 / \% 56$ \\
\hline & & & TOPLAM & 684 & 171 & 171 & 171 & 171 \\
\hline
\end{tabular}

Haber metinleri kullanılan dil ve seçilen kelimeler, yapılan çağrışımlar ve oluşturulmak istenen alg1, steriotipleştirme ve geleneksel kabuller, tecrübe ve hafiza ile sosyal bağlam bakımından incelendiğinde sosyal kesimlerin bilişsel modelleri ve toplumsal zihniyet yapıları daha açı görülebilmektedir. "Yani daha üzerinde otomobil olmadan sadece batarya maliyeti bu, otomobilin yazılımının maliyeti buna dahil değil" (Habertürk / 03.01.2020) ifadeleri Devrim Arabası hakkında yapılan "ilk Türk otomobili için 900 bin lira harcandi" (Hürriyet / 01.11.1961), "DEVRIM'in maliyeti”" (Vatan / 01.11.1961) gibi maliyeti öne çıkaran haberleri anımsatmaktadır. "Yerli otomobilin bataryası Çin'den, entegrasyon Almanya'dan, tasartm Italya'dan" (Cumhuriyet / 28.01.2020) ifadeleri ise yine Devrim Arabası hakkında yapılan "Devrim otomobilinin \%80 yerli Türk malzemesi ile yapıldığına inanmak memleketimiz muvacenehesinde çok güçtür. Motoru Türkiye'de nasıl yapılır? Kapısının tokmağını ve kilidini yaptığımız bile şüphelidir" (Yeni İstanbul / 01.11.1961) ve "Her motor parçasının tek tek taklidini 
dökerek bir otomobil yapmışız. Neden yapamazmışız? Bu usul ile daha ince, daha dolambaçlı makineler de yapabiliriz" (Dünya / 03.11.1961) haberlerini hatırlatmaktadır. Yaklaşı 60 yıl geçmiş olmasına rağmen iki projeye yönelik eleştiri ve tutumların bu kadar benzer olması bazı toplumsal kesimlerin zihinsel alışkanlıklarını devam ettirdiklerini göstermektedir. Ancak bu yönde ve üslupta haberlerin sayısının Türkiye'nin Otomobili projesi için ihmal edilebilecek ölçüde az olduğu söylenebilir.

Tablo 5: Türkiye'nin Otomobiline ilişkin örnek ifadeler

\begin{tabular}{|c|c|c|c|}
\hline & \multicolumn{2}{|l|}{ Gazete/Tarih } & Örnek İfade \\
\hline \multicolumn{4}{|l|}{ İLGİ } \\
\hline \multirow{4}{*}{ Olumlu } & $\begin{array}{l}\text { Sabah } \\
27.12 .2019\end{array}$ & l & $\begin{array}{l}\text { Türkiye'nin yerli otomobiline hayran kaldılar! İlk günden sipariş yağdı. Türkiye'nin } \\
\text { otomobili dünya gündeminin ilk sırasına çıtı. }\end{array}$ \\
\hline & $\begin{array}{l}\text { Hürriyet } \\
29.12 .2019\end{array}$ & 1 & $\begin{array}{l}\text { "Türkiye'nin Otomobili" Güneydoğu'da çok beğenildi. Otomobili çok beğendiğini } \\
\text { vurgulayarak, "Artık sonra kendi aracimızı da üretmemiz çok önemli bir gelişme. } \\
\text { Türkiye'nin teknolojide geldiği noktayı gösteriyor. Vatandaş olarak gurur duydum. }\end{array}$ \\
\hline & $\begin{array}{l}\text { Yeni Şafak } \\
10.01 .2020\end{array}$ & / & Türkiye'nin Otomobili", toplumun her kesiminin beğeni ve takdirini kazandı. \\
\hline & $\begin{array}{l}\text { Yeni Akit } \\
27.12 .2019\end{array}$ & I & $\begin{array}{l}\text { Türkiye'nin merakla beklediği yerli otomobilin iki modeli Cumhurbaşkanı Recep Tayyip } \\
\text { Erdoğan'ın katılımıla tanıtıldı. }\end{array}$ \\
\hline Olumsuz & - & & - \\
\hline \multirow[t]{3}{*}{ ÖNEM } & & & \\
\hline & $\begin{array}{l}\text { Yeni Akit } \\
16.01 .2020\end{array}$ & I & $\begin{array}{l}\text { Türkiye'nin Otomobili birçok sektörün önünü açacak. Gemlik fabrikasını 12-18 ay içinde } \\
\text { tamamlarız. }\end{array}$ \\
\hline & $\begin{array}{l}\text { Sabah } \\
27.12 .2019\end{array}$ & l & $\begin{array}{l}\text { Türkiye'nin Otomobili projesindeki teknoloji birikimimiz diğer pek çok sektörün de önünü } \\
\text { açacak, ateşleyicisi olacaktır. }\end{array}$ \\
\hline \multirow[t]{2}{*}{ Olumlu } & $\begin{array}{l}\text { Hürriyet } \\
30.12 .2019\end{array}$ & 1 & $\begin{array}{l}\text { "Yapılan bir otomobilden fazlasıdır, teknolojik dönüşümdür, dijital ekonomiye geçiştir. Tek } \\
\text { başına } 20 \text { bin ilave istihdamdır. } 7,5 \text { milyar dolar daha az cari açıktır. Gayrisafi milli hasılaya } \\
50 \text { milyar dolar katkıdır." dedi. }\end{array}$ \\
\hline & $\begin{array}{l}\text { Yeni Şafak } \\
29.12 .2019\end{array}$ & I & Türkiye'yi otomotiv sektöründe küresel aktöre dönüştürecek milli otomobil projesi. \\
\hline Olumsuz & $\begin{array}{l}\text { Cumhuriyet } \\
28.01 .2020\end{array}$ & I & Yerli otomobilin bataryası Çin'den, entegrasyon Almanya'dan, tasarım İtalya'dan. \\
\hline
\end{tabular}

BAŞARI

Hürriyet

28.12.2019

Sözcü

28.12.2019

Olumlu

Akşam

30.12.2019

Sabah

15.01.2020

Habertürk

Olumsuz

DESTEK

Yeni Akit

28.12.2019

Sabah

07.01.2020

31.12.2019

Karar

29.12.2019

Yeni Şafak

10.01.2020

Olumsuz
Milliyet

İlk modelini ve bir konsept aracını gün ışığına çıkaran TOGG, Türk Otomotiv endüstrisinin kalbi olan Marmara Bölgesi'nde kurulacak fabrikasının temelini 2020 yılında atacak. 2030 yılına kadar ise fikri ve sinai mülkiyet hakları tamamen kendisine ait bir ortak e-platform üzerine 5 farklı model üretecek.

Türkiye'nin Otomobili Girişim Grubu (TOGG), yıllık 175 bin adetlik kapasitesiyle 2022 yılında üretime başlayacak Gemlik'teki fabrikanın temelini bahar ayında atmaya hazırlaniyor.

Markası bizim olacak, tasarımı bizim olacak. Lisans satacağız. Montaj yapmayacağız, montaj yaptıracağız. Başkasının patenti için çalışmayacağız. 15 yılda en az 22 milyar lira yatırım yapılacak.

Yerli otomobil o tarihte tamamlanacak: Yerli otomobil için siparişler peşi sıra gelirken,

"Türkiye'nin Otomobili birçok sektörün önünü açacak. Gemlik fabrikasını 12-18 ay içinde tamamları"

/ Yani daha üzerinde otomobil olmadan sadece batarya maliyeti bu... otomobilin yazılımının maliyeti buna dahil değil.

Edirne'deki sivil toplum kuruluşları ve iş adamları olarak önümüzdeki günlerde bir kampanya başlatacağız ve alacağımız araç sayısını deklare edeceğiz. ETSO olarak da yerli otomobilin destekçisiyiz. Milli duygularla üretilmiş, tamamen çevreci bir otomobil.

/ Yerli otomobile talep yağıyor: İstanbul Havalimanı'nda görevli 750 taksici, "Türkiye'nin Otomobili'ne destek verdi. Taksiciler, hizmetlerini yerli otomobil ile vermek istiyor.

I Anadolu'nun dört bir tarafından gelen "almaya hazırız" mesajları ön ödeme listesine alınacak. Türkiye'nin Otomobili Girişim Grubu'nun (TOGG) dışında başlatılan çalışma ile otomobili almak isteyenlerin sayısı ve ödeyecekleri rakam belirlenecek.

Türkiye'nin otomobiline her kesimden destek geldi. Toplumda ayrışmalara yol açan Şehir Hastaneleri ve Kanal İstanbul gibi projelerin aksine Türkiye'nin otomobiline her kesimden destek geldi

Cumhuriyet / Araba daha ortada yok, ne zaman üretileceği belli değil. Motoru ise zaten yok ama bu yerli 29.01.2020 ve milli. Kafayı yerli ve milliye takmışlar. 
Türkiye'nin Otomobili ile ilgili haberlere genel bir çerçeveden bakıldığında olumlu yaklaşım doğrudan göze çarpmaktadır. Olumsuz haberin çok az olması ve nötr haberlerin daha teknik ve bilgi esaslı olması olumlu haberlerin toplumsal zihniyeti daha güçlü şekilde yansıtabileceğini göstermektedir. "Türkiye'nin otomobili dünya gündeminin ilk sırasına çıktı" (Sabah / 27.12.2019) ifadesinde tarihsel hafızaya bir gönderme söz konusudur. Çünkü dünyada otomobil ilk defa yapılmamakta ve bahsedildiği gibi dünyanın yüksek ilgi göstermesi için görünürde mantıklı bir sebep bulunmamaktadır. Ancak Türkiye'nin ilk defa dünya standartlarında çağın teknolojisine uygun otomobil yapmayı başarabilmesi hem toplumun kendine bakışında hem de dünyanın Türkiye'ye bakışında bir değişim etkisi oluşturabilmektedir. Bu ifade "biz başaramaylz" ve "bize yaptırtmazlar" düşüncesindeki iç aktörlere, "Türkiye yapamaz" şeklinde düşünen diş aktörlere karşı, bütün önyargılara rağmen "biz başardlk" mesajı taşımaktadır.

"Türkiye'nin Otomobili projesindeki teknoloji birikimimiz diğer pek çok sektörün de önünü açacak” (Sabah / 27.12.2019), "Yapllan bir otomobilden fazlasıdır, teknolojik dönüşümdür, dijital ekonomiye geçiştir" (Hürriyet / 30.12.2019) ve "Türkiye'yi otomotiv sektöründe küresel aktöre dönüştürecek milli otomobil projesi" (Yeni Şafak / 29.12.2019) ifadeleri projenin önemsendiğinin göstergesidir. Bu ifadeler toplumsal kesimlerin projenin ne kadar kritik bir öneme sahip olduğunu ve Türkiye açısından neleri değiştirebileceğinin bilincinde olunduğunu göstermektedir. Teknolojik dönüşüm ve küresel aktöre dönüşüm vurguları arka planda toplumsal zihniyetteki dönüşümü işaret etmektedir. Dijital ekonomiye geçiş ve küresel aktör olma ifadeleri dünyadaki değişimi kavrayan, kendi yeteneklerinin farkında olan ve rakiplerinin niteliklerini çözümleyerek iddia ve strateji geliştirmesi gerektiğini bilen bir zihniyetin oluşmaya başladığını göstermektedir. "Markası bizim olacak, tasarımı bizim olacak. Lisans satacă̆ız. Montaj yapmayacă̆ız, montaj yaptıracă̆ız. Başkasının patenti için çalışmayacağız" (Akşam / 30.12.2019) ifadeleri montaj sanayinden ve lisans altında üretimden tasarım ve marka temelli bir modele geçilmesi gerektiğinin bilincinde olan bir toplumsal zihniyetin geliştiğinin açık göstergesidir.

"Işs adamları olarak önümüzdeki günlerde bir kampanya başlatacağız" (Yeni Akit / 28.12.2019), "Yerli otomobile talep yağıyor" (Sabah / 07.01 .2020), "Otomobil ve şoför esnafından Türkiye'nin Otomobiline destek" (Hürriyet / 29.12.2019) ve "Anadolu'nun dört bir tarafindan gelen almaya hazırız mesajlart" (Milliyet / 31.12.2019) ifadeleri desteği göstermektedir. Bu ifadeler toplumun projeyi sahiplendiği ve destek vermeye istekli olduğu anlamına gelmektedir. Toplumsal desteğin bu ölçüde belirgin ve yüksek olması, teknolojik ve ekonomik gelişme ile toplumsal refah ve ülkeler arası güç mücadelesi arasındaki bağın farkında olunduğunu, bu doğrultuda siyasetin ve girişimin diğer aktörlerinin desteklenmesi gerektiğinin bilincinde olunduğunu göstermektedir. Toplumsal destek hem maddi hem de manevi anlamda oldukça itici bir unsur olarak siyasete cesaret verir, meşruiyet sağlar, kasti yıpratma stratejilerinin etkisini azaltır, moral ve motivasyonu artırır, iç talep oluşturarak projenin olgunlaşması için zaman kazandırır. Günümüz toplumu ülke için kritik bir projede vereceği desteğin etkilerinin farkında, özgüveni ve öz yeterlilik algısı yüksek, insiyatif ve sorumluluk almaktan çekinmeyen bir bilince ulaşmıştır.

\section{Sonuç ve öneriler}

Toplumsal aktörlerin sosyal alandaki davranış, tutum ve tavırlarının temelinde zihniyet yapıları bulunmaktadır. Toplumsal zihniyet tarihsel ve kültürel süreçlerin sonucunda oluşmakta ve zamanla dönüşebilmektedir. Çalı̧̧ma fenomenolojik kurumsalcı bir perspektifle tasarlanmış ve sosyal olayların arka planındaki zihinsel olgulara ulaşılmaya çalışılmıştır. Bu doğrultuda çalışma "Devrim Arabası" ve “Türkiye'nin Otomobili” projelerine toplumun bakışındaki zihinsel yapıları ve her iki dönem zihniyeti arasındaki değişimi sorgulamıştır. Bu amaçla ulusal gazetelerde yer alan konuya ilişkin haberler analiz edilmiş ve sonuçlar karşılaştırılmıştır.

Haberlerin içerikleri genel olarak her iki projenin toplumda olumlu karşılandığını göstermektedir. Alt kategoriler açısından incelendiğinde önem verme ve başarılı olacağına inanma konusunda her iki dönemde de olumlu bir yaklaşım söz konusudur. İlgi gösterme ve destek olma anlamında toplumsal tavrın belirgin bir şekilde değiş̧tiği anlaşılmaktadır. İlgi gösterme \%16'dan \%63'e, destek olma \%7'den \%43'e yükselmiştir. Bu bulgular toplumun Devrim Arabası projesini önemsediğini ve başarılı olacağına inandığını ancak göstereceği ilgi ve desteğin meydana getireceği olumlu etkiyi kavrayamadığı ya da 
buna cesaret edecek özgüveni kendinde bulamadığını göstermektedir. Türkiye'nin Otomobili projesine ilgi ve desteğin belirgin bir şekilde artmasında eğitim düzeyi, işgücü nitelikleri, entelektüel sermaye, finansal sermaye, alt yapı imkânları, satınalma gücü, teknolojik yetenek, iş yapma tecrübesi, uluslararası iş birlikleri ve ortaklıklar, kitle iletişim imkânları gibi diğer alanlardaki gelişmelerin etkisi bulunabilir. Ancak bu alanlardaki ilerleme ile toplumsal zihniyetteki değişim arasında çok güçlü nedensel ilişkiler söz konusudur. Diğer toplumsal unsurların değişebilmesi ancak toplumsal zihniyetin dönüşmesi ile mümkün olduğu için bugün gelinen noktada teknolojik yetenek ve iş yapma tecrübesi gibi somut unsurların etkisini toplumsal zihniyetteki dönüşüm ile birlikte ele almak gerekmektedir.

Bu çalışmada Devrim Arabası ve Türkiye'nin Otomobili projelerinin başarı ya da başarısızlığındaki etmenler sorgulanmamaktadır. Araştırmada her iki projeye toplumun yaklaşımı zihniyet açısından değerlendirilmiş ve toplumsal zihniyetteki dönüşüm tartışılmıştır. Bu tür projelerin sonuçları tek başına zihniyet ile açıklanamayacağı gibi gazete manşetlerinin projenin başarısızlığının ana etmeni olarak sunulması da gerçekçi görünmemektedir. Şimşek'in (2017: 10-19-110-204-216-217) Devrim Arabası'na basının çoğunlukla olumsuz yaklaştı̆̆ 1 ve söz birliği etmiş̧̧esine Devrim'in başarısızlığından bahsettikleri iddiası (Şimşek, 2017: 110) ile bu araştırmada elde edilen bulgular örtüşmemektedir. Aşık'ın (2020: 110-119) tüm basının Devrim Arabası ile ilgili aleyhte tavır takındı̆̆ yönündeki düşüncenin doğru olmadığı, bütün gazetelerin Devrim'i karaladığının söylenemeyeceği ve üretime engelin basın olarak lanse edilmesinin tarihi bir yanılgı olduğu yönündeki tespitlerini, bu araştırmanın bulguları desteklemektedir.

Toplumların geçmiş dönemlerine ilişkin zihniyet çalışmalarında zorunlu olarak ikincil kaynaklar kullanılmaktadır. Şiir, roman, hikâye, masal gibi edebi metinler üzerinden çözümlemeler yapılabildiği gibi mektup, günlük ve hatıratlar gibi kişisel metinler de kullanılabilmektedir. Aynı zamanda gazeteler, dergiler, bilimsel eserler, kamu ve şirket arşivleri, dernek ve vakıfların kayıtları gibi kolektif dokümanlar da toplumsal zihniyetin anlaşılmasında materyal olarak seçilebilmektedir. Bu araştırmada sadece gazeteler incelenmiştir ve bu durum çalışmanın sınırlılığı olarak gösterilebilir. Bu konuda bundan sonra yapılacak çalışmalar, iki projeye çıkar gruplarının, uzmanların ve köşe yazarlarının görüş ve yaklaşımlarını eleştirel söylem analizi yöntemiyle derinlemesine irdeleyebilir. Böylelikle projeye destek verme veya karşı çıkma tavırlarını iktidar, güç ve söylem ilişkisi bağlamında değerlendirerek iktidarı elde etme ya da iktidarı koruma güdüsünün gösterilen tavrı belirlemedeki rolü açığa çıkarılabilir. Bunun için söylem ve güç ilişkisi ile basın ve çıkar odakları ilişkisinin bir arada ele alınması faydalı bir bakış açısı olarak önerilebilir. Ayrıca ilk projenin yarım kalması ikincisinin başarılabilmesinde yetişmiş işgücü, teknolojik yetenek ve birikim, sermaye gücü, hükümet ve bürokrasinin rolü araştırılabilir.

Toplumsal zihniyet bireysel ve kolektif aktörlerin herhangi bir konudaki eylem, tercih ve tavırlarını derinden ve istikrarlı bir şekilde etkilemektedir. Aktörlerin tercih ve eylemlerinden ya da söylem ve metinlerdeki dilden toplumsal zihniyete dair izlere ulaşılabilmektedir. Bu çalışmada aralarında yaklaşık yarım asırlık bir zaman farkı bulunan iki benzer projeye farklı toplum kesimlerini temsil eden ve farklı görüşleri yansıtan gazetelerin haberlerindeki dil çözümlenerek toplumsal zihniyet açığa çıkarılmıştır. Toplumsal zihniyetin ülkenin geleceğini ilgilendiren projelerde ilgi gösterme ve destek olma konusunda önemli ölçüde dönüştüğü sonucuna ulaşılmıştır. Sosyal, ekonomik, politik ve uluslararası meselelerde toplumun geniş kesimlerinin uzlaşısı ve iş birliği olmadan başarı ve sonuç elde etmek oldukça zordur. Toplumun, bu tür projelerin toplumsal refahta, uluslararası rekabette, ülkeler arası güç dengesinde ve bağımlılık ilişkilerinin yönetilmesinde oynadığı rolün bilincinde olarak davranması ve tavrını belirlemesi toplumsal zihniyetin zaman içerisinde ne ölçüde ve ne yönde değiştiğinin önemli bir göstergesidir. Günümüz toplumu 1960'lı yıllara göre ülkenin geleceğini ilgilendiren bir meselede daha fazla ilgi gösteren, insiyatif alan, desteğini açıkça ifade eden ve vereceği desteğin sonuca etki edeceğine inanan bir toplumsal bilinç seviyesine ulaşmıştır. Bu nedenle çalışma, toplumsal zihniyetin iki proje arasında geçen zaman aralığında projenin muhtemel sonuçlarını kavrayabilme, projenin akıbeti ile kendi rolü arasında ilişki kurabilme, aktif bir şekilde insiyatif alacak özgüveni ortaya koyma konularında belirgin bir şekilde dönüştüğünü öne sürmektedir. 


\section{Kaynakça}

Ainsworth, S. ve Hardy, C. (2004). Discourse and identities. D. Grant, C. Hardy, C. Oswick ve L. Putman (Ed), Sage handbook of organizational discourse içinde (s. 153-173). Sage.

Akşam (1961, 28-30-31 Ekim / 23 Kasım; 2019, 27-31 Aralık; 2020, 1-30 Ocak)

$\begin{array}{llll}\text { Alexa } & \text { (2020). } & 13 & \text { Eylül }\end{array}$ https://www.alexa.com/topsites/category/Top/World/Türkçe/Basın_ve_Yayın erişildi.

Alvesson, M. ve Karreman, D. (2000a). Taking the linguistic turn in organizational research: Challenges, responses, consequences. Journal of Applied Behavioral Science, 36(2), 136-158. https://doi.org/10.1177/0021886300362002

Alvesson, M. ve Karreman, D. (2000b). Varieties of discourse: On study of organizations through discourse analysis. Human $\quad$ Relations, $1125-1149$. https://doi.org/10.1177/0018726700539002

Anadolu Ajansı (2020, 06 Ocak). 10 Ağustos 2020 tarihinde https://www.aa.com.tr/tr/politika/bakanvarank-turkiyenin-otomobilinin-tasarimlari-icin-tescil-basvurulari-yapildi/1693428 adresinden erişildi.

Anık, C. (2011). Toplumsal zihniyet aracılığg1yla sosyal kontrol. Uluslararası Terörizm ve Güvenlik Dergisi, 2(1), 101-115. https://www.acarindex.com/dosyalar/makale/acarindex-1423936139.pdf

Aşık, S. (2020). Devrim Arabaları: Ilk kez yayınlanan arşiv belgeleriyle bir devrin hikâyesi. Kopernik.

Barley, S.R. ve Tolbert, P.S. (1997). Institutionalization and structuration: Studying the links between action and institution. Organization Studies, 18(1), 93-117. https://doi.org/10.1177/017084069701800106

Berger, P.L. ve Luckmann, T. (1967). The social construction of reality. Doubleday.

Bottomore, T. ve Nisbet, R. (2002). Yapısalcılık. (B.Toprak, Çev.), T.Bottomore ve R.Nisbet (Ed). Sosyolojik çözümlemenin tarihi içinde (s. 555-593). Ayraç. (Orijinal yayın tarihi, 1978)

Bourdieu, P. (2018). Bir pratik teorisi için taslak. (N.Ökten, Çev.). İstanbul Bilgi Üniversitesi Yayınları. (Orijinal yayın tarihi, 1972)

Cohen, I.J. (2013). Yapılaşma teorisi ve toplumsal praxis. (Ü.Tatlıcan, Çev.), A.Giddens ve J.Turner (Ed). Günümüzde sosyal teori içinde (s. 307-345). Say. (Orijinal yayın tarihi, 1987)

Coleman, J.S. (1986). Social theory, social research and a theory of action. American Journal of Sociology, 91(6), 1309-1335. https://www.jstor.org/stable/2779798

Collins, R. (1981). On the microfoundations of macrosociology. American Journal of Sociology, 86(5), 984-1014. https://www.jstor.org/stable/2778745

Collins, R. (2015). Sosyolojide dört ana gelenek. (Ü.Tatlıcan, Çev.). Sentez. (Orijinal yayın tarihi, 1994)

Cumhuriyet (1961, 19-29-30 Ekim; 2019, 27-31 Aral1k; 2020, 1-30 Ocak)

Deetz, S. (1996). Describing differences in approaches to organization science: Rethinking Burrell and Morgan and their legacy. Organization Science, 7(2), 191-207. https://doi.org/10.1287/orsc.7.2.191

DiMaggio, P.J. (1997). Culture and cognition. Annual Review of Sociology, 23, 263-287. https://doi.org/10.1146/annurev.soc.23.1.263

Dünya (1961, 07-29-30 Ekim / 01-03 Kasim)

Elliott, A. (2017). Çăgdaş sosyal teoriye giriş. (İ.Yıldız ve A.G.Baran, Çev.). Dipnot. (Orijinal yayın tarihi, 2014)

Fairclough, N. (2013). Critical discourse analysis: The critical study of language. (Second Edition). Routledge.

Fairclough, N. (2003). Analysing discourse: Textual analysis for social research. Routledge.

Fairhurst, G.T. ve Cooren, F. (2004). Organizational language in use: Interaction analysis, conversation analysis and speech act schematics. D.Grant, C.Hardy, C.Oswick ve L.Putman (Ed). Sage handbook of organizational discourse içinde (s. 131-152). Sage.

Farberman, H.A. (1970). Mannheim, Cooley and Mead: Toward a social theory of mentality. Sociological Quarterly, 11(1), 3-13. https://www.jstor.org/stable/4105272

Foucault, M. (2014). Bilginin arkeolojisi. (V.Urhan, Çev.). Ayrıntı. (Orijinal yayın tarihi, 1969)

Friedland, R. ve Alford, R.R. (1991). Bringing society back in: Symbols, practies and institutional contradictions. W.W.Powell ve P.J.DiMaggio (Ed). The new institutionalism in organizational analysis içinde (s. 232-263). University of Chicago Press. 
Giddens, A. (1984). The constitution of society: Autline of the theory of structuration. University of California Press.

Giddens, A. (2013). Yapısalcılık, post-yapısalcılık ve kültürün üretimi. (Ü.Tatlıcan, Çev.), A.Giddens ve J.Turner (Ed). Günümüzde Sosyal Teori içinde (s. 219-251). Say. (Orijinal yayın tarihi, 1987)

Goffman, E. (1983). The interaction order: American sociological association, 1982 presidential address. American Sociological Review, 48(1), 1-17. https://doi.org/10.2307/2095141

Habertürk (2019, 27-31 Aralık; 2020, 1-30 Ocak)

Habertürk (2020, 18 Temmuz). 10 Ağustos 2020 tarihinde https://www.haberturk.com/dunden-buguneyerli-otomobil-2747503-ekonomi adresinden erişildi.

Havadis (1961, 30 Ekim)

Heracleous, L.T. (2004). Interpretivist approaches to organizational discourse. D.Grant, C.Hardy, C.Oswick ve L.Putman (Ed). Sage handbook of organizational discourse içinde (s. 175-192). Sage.

Hirsch, P.M. (1997). Sociology without social structure: Neo-institutional theory meets brave new world. American Journal of Sociology, 102(6), 1702-1723. https://doi.org/10.1086/231132

Holt, R. ve Sandberg, J. (2013). Fenomenoloji ve örgüt teorisi. (A.Elverici ve H.C. Demir, Çev.). H. Tsoukas ve R. Chia (Ed). Felsefe ve örgüt teorisi içinde (s. 215-250). Nobel. (Orijinal yayın tarihi, 2011).

Hürriyet (1961, 30 Ekim / 01 Kasım; 2019, 27-31 Aralık; 2020, 1-30 Ocak)

Jepperson, R.L. (1991). Institutions, institutional effects and institutionalism. W.W.Powell ve P.J.DiMaggio (Ed). The new institutionalism in organizational analysis içinde (s. 143-163). University of Chicago Press.

Jepperson, R.L. ve Meyer, J.W. (2011). Multiple levels of analysis and the limitations of methodological individualisms. Sociological Theory, 29(1), 54-73. https://doi.org/10.1111/j.14679558.2010.01387.x

Kala, M. E. (2019). Zihnin ontolojik yapısı ve zihniyet bağımlı dilin "ben" ahlakı. Felsefe Dünyası Dergisi, 69, 169-184. https://dergipark.org.tr/tr/pub/felsefedunyasi/issue/58338/851170

Karar (2019, 27-31 Aralık; 2020, 1-30 Ocak)

Kikkawa, T. (2014). Social mentality in contemporary Japan. Osaka University Press

Kudret (1961, 28-29-30 Ekim / 01 Kasim)

Layder, D. (2006). Understanding social theory. (Second Edition). Sage.

Maigret, E. (2014). Medya ve iletişim sosyolojisi. (H.Yücel, Çev.). İletişim. (Orijinal yayın tarihi, 2004)

Mayring, P. (2011). Nitel sosyal araştırmaya giriş. (A.Gümüş ve M.S. Durgun, Çev.). Bilgesu. (Orijinal yayın tarihi, 1990)

Mead, G.H. (2017). Zihin, benlik ve toplum. (Y.Erdem, Çev.). Heretik. (Orijinal yayın tarihi, 1934)

Meyer, J.W. ve Rowan, B. (1977). Institutionalized organizations: Formal structure as myth and ceremony. American Journal of Sociology, 83(2), 340-363. https://www.jstor.org/stable/2778293

Meyer, J.W. (2008). Reflections on institutional theories of organizations. R.Greenwood, C.Oliver, K.Sahlin ve R.Suddaby (Ed). Sage handbook of organizational institutionalism içinde (s. 788809). Sage.

Meyer, J.W. (2010). World society, institutional theories and the actor. Annual Review of Sociology, 36, 1-20. https://doi.org/10.1146/annurev.soc.012809.102506

Meyer, J.W. (2017). Reflections on institutional theories of organizations. R.Greenwood, C.Oliver, T.B.Lawrence ve R.E. Meyer (Ed). Sage handbook of organizational institutionalism içinde (s. 831-852). (2nd Edition). Sage.

Milliyet (1961, 28-29-30 Ekim / 01-06 Kasım; 2019, 27-31 Aralık; 2020, 1-30 Ocak)

Öncü (1961, 09-30 Ekim / 01 Kasım)

Phillips, N. ve Malhotra, N. (2008). Taking social construction seriously: Extending the discursive approach in institutional theory. R.Greenwood, C.Oliver, K.Sahlin ve R.Suddaby (Ed). Sage handbook of organizational institutionalism içinde (702-720). Sage.

Powell, W.W. ve Colyvas, J.A. (2008). Microfoundations of institutional theory. R.Greenwood, C.Oliver, K.Sahlin ve R.Suddaby (Eds). Sage handbook of organizational institutionalism içinde (s. 276-298). Sage.

Putnam, L.L. ve Fairhurst, G.L. (2001). Discourse analysis in organizations. F.M.Jablin ve L.L. Putnam (Ed). Sage handbook of organizational communication içinde (s. 78-136). Sage. 
Sabah (2019, 27-31 Aralı; 2020, 1-30 Ocak)

Sarup, M. (2019). Post-yapısalcıllk ve postmodernizm. (A.Güçlü, Çev.). Pharmakon. (Orijinal yayın tarihi, 1993)

Scott, W.R. (2008). Approaching adulthood: The maturing of institutional theory. Theory Sociology. 37, 427-442. http://dx.doi.org/10.1007/s11186-008-9067-z

Sewell, W.H. (1992). A theory of structure: Duality, agency and transformation. American Journal of Sociology, 98(1), 1-29. https://www.jstor.org/stable/2781191

Similarweb (2020). 13 Eylül 2020 tarihinde websites/turkey/category/news-and-media/ adresinden erișildi.

Son Havadis (1961, 30 Ekim)

Son Posta (1961, 30 Ekim)

Sözcü (2019, 27-31 Aralık; 2020, 1-30 Ocak)

$\begin{array}{lllll}\text { Speedmedya } & \text { (2020). } & 13 & \text { Eylül } & 2020\end{array}$ http://app.speedmedya.com/Report/ReportDetail?ReportCode $=110$ adresinden erişildi.

Şimşek, M. (2017). Yarım kalan devrim rüyası: Cumhuriyet dönemi endüstrileşme maceramız. (3.Bask1). Alfa.

Tercüman (1961, 07-30 Ekim)

Tolbert, P.S. ve Zucker, L.G. (1996). The institutionalization of institutional theory. S.Clegg, C.Hardy ve W.Nord (Ed). Handbook of organization Studies içinde (s. 175-190). Sage.

Ulus (1961, 04-30 Ekim / 01 Kasim)

Van Dijk, T.A. (1988). News as discourse. Lawrence Erlbaum Associates.

Van Dijk, T.A. (1993). Principles of critical discourse analysis. Discourse \& Society, 4(2), 249-283. https://doi.org/10.1177/0957926593004002006

Van Dijk, T.A. (2001). Multidisciplinary CDA: A plea for diversity. R. Wodak ve M. Meyer (Ed). Methods of critical discourse analysis içinde (s. 95-120). Sage.

Van Dijk, T.A. (2008). Discourse and context: A sociocognitive approach. Cambridge University Press.

Van Dijk, T.A. (2009). Society and discourse: How social contexts influence text and talk. Cambridge University Press.

Van Dijk, T.A. (2014). Discourse and knowledge: A sociocognitive approach. Cambridge University Press.

Van Dijk, T.A. (2015). Critical discourse analysis. D. Tannen, H. E. Hamilton ve D. Schiffrin (Ed). Handbook of discourse analysis içinde (s. 466-485). (2nd Edition). Wiley Blackwell.

Vatan (1961, 14-30 Ekim; 01-27-28-29-30 Kasim)

Weick, K.E. (1993). The collapse of sensemaking in organizations: The Mann Gulch disaster. Administrative Science Quarterly, 38(4), 628-652. https://doi.org/10.2307/2393339

Wiley, N. (1988). The micro - macro problem in social theory. Sociological Theory, 6(2), 254-261. https://doi.org/10.2307/202119

Woff, K.H. (2002). Fenomenoloji ve sosyoloji. (H. Rizatepe, Çev.). T.Bottomore ve R.Nisbet (Ed). Sosyolojik çözümlemenin tarihi içinde (s. 497-553). Ayraç. (Orijinal yayın tarihi, 1978)

Yeni Akit (2019, 27-31 Aralık; 2020, 1-30 Ocak)

Yeni İstanbul (1961, 30 Ekim / 01 Kasım)

Yeni Sabah (1961, 30-31 Ekim)

Yeni Şafak (2019, 27-31 Aralık; 2020, 1-30 Ocak)

Yiğit, Z. (2009). Anadolu toplumu zihinsel yapısı bağlamında Kabadayı filmi. Turkish Studies, 4(8), 2492-2507. http://dx.doi.org/10.7827/TurkishStudies.1054

Zucker, L.G. (1977). The role of institutionalization in cultural persistence. American Sociological Review, 42(5), 726-743. https://doi.org/10.2307/2094862 


\section{Etik kurul onayı}

Kamuya açık gazete haberlerinin analiz materyali olarak kullanılması nedeniyle bu araştırma etik kurul izni gerektirmeyen çalışmalar arasında yer almaktadır.

Çıkar çatışması beyanı

Araştırma herhangi bir kurum, kişi veya kuruluş ile herhangi bir çıkar çatışmasına sebep olmamaktadır.

Teşekkür -destek beyanı

Devrim Arabası ile ilgili ulaşamadığım bazı gazete haberlerini kişisel arşivinden benimle paylaşarak araştırmama destek olan Dr. Süleyman Aşık'a katkılarından dolayı teşekkür ederim. 